\title{
DÜNYADAKİ ÖRNEKLER IŞIĞINDA YATIRIM YOLUYLA VATANDAŞLIK UYGULAMASINA ELEŞTIREL BİR BAKIŞ
}

\author{
A CRITICAL REVIEW OF THE APPLICATION OF CITIZENSHIP BY INVESTMENT \\ IN LIGHT OF THE EXAMPLES IN THE WORLD
}

Talat KAYA* $\stackrel{m}{m}$ (iD)

\begin{tabular}{l} 
Makale Bilgi \\
\hline Gönderi: 14/12/2020 \\
Kabul : 10/03/2021 \\
Anahtar Kelimeler \\
\hline Yatırım Yoluyla \\
Vatandaşlı, \\
Yatırımcı Programı, \\
Vatandaşlı Bağı.
\end{tabular}

Article Info

Received: 14/12/2020 Accepted: 10/03/2021

\section{Keywords}

Citizenship by

Investment, Investor Program, Citizenship Bond.

\begin{abstract}
Özet https://dai.org/l0.21492/inuhfd.840448 doi

Yatırım yoluyla vatandaşlık kavramı yabancı kişinin ülkeye yaptığı doğrudan veya dolaylı yatırım veyahut bağış karşılığında, yatırım yapılan devlet tarafından verilen vatandaşlık olarak tanımlanabilir. Yatırım yoluyla vatandaşlık verilmesi konusunda geleneksel uygulama, ülkeye belli bir yatırım getirilmesine ilave olarak, yatırım yapan kişinin girişimcilik ve istihdam oluşturma gibi belli vasıflara haiz olmasını aramaktadır. Yatırım yoluyla vatandaşlık verilmesi uygulamaları son 30 yılda ise yatırımcının vasfını göz ardı eden, buna mukabil getirilen ekonomik katkıyı ön planda tutan yatırımcı programları çerçevesinde gelişmiştir. Başlangıçta Karayip bölgesinde yer alan küçük ada devletlerince yürütülen yatırımcı programları zamanla $\mathrm{ABD}$, bazı $\mathrm{AB}$ ülkeleri ve Türkiye de dahil olmak üzere geniş bir coğrafyada uygulanır hale gelmiştir. Bununla birlikte, getirilen ekonomik katkının tek kriter olarak arandığı programlar, güvenlik, vergi, seçme ve seçilme hakkı, askerlik yükümlülüğü ve ekonomik fayda başlıkları altında ulusal ve uluslararası düzeyde ciddi eleştirilerin gündeme gelmesine neden olmuştur. Söz konusu eleştirilerin temelinde ise vatandaşlığın metalaştırılması ve aidiyet bağı tesis edilmeden vatandaşlı̆̆ın verilmesi yatmaktadır.
\end{abstract}

\begin{abstract}
The concept of citizenship by investment can be defined as the citizenship granted by the invested state in return for direct or indirect investment or donation made by the foreigner in the country. The traditional practice of granting citizenship by investment seeks investors having certain qualifications such as entrepreneurship and employment creation, in addition to the investment they brought to the country. In the last 30 years, however, the practices of granting citizenship by investment have developed within the framework of investor programs disregarding the qualifications of the investor but prioritizing economic contribution. Investor programs, initially conducted by small island states in the Caribbean region, have over the time applied in a wide range of geographic areas including the United States, some of the EU countries and Turkey. However, these programs have sparked serious criticism nationally and internationally, under the headings of security, tax, voting rights, military service obligation and economic benefit. The main bases of these criticisms are, though, the commodification of citizenship and the granting of citizenship without establishing a genuine link.
\end{abstract}




\section{GİRIŞ}

Vatandaşlık en basit tanımla, kişinin devlete aidiyetini gösteren hukuki ve siyasi bağı ifade eder ${ }^{1}$. Vatandaşlık bağı nedeniyle kişi, vatandaşı olduğu devletin diplomatik korumasından yararlanır, seçme-seçilme ve kamu hizmetlerine girme gibi birtakım haklara sahip olur ${ }^{2}$. Vatandaşlık aynı zamanda ülke savunmasına katılma, vergi verme, devletin koymuş olduğu kurallara uyma ve hepsinden önemli olarak sadakat yükümlülüğünü içerir ${ }^{3}$. Bu bağlamda vatandaşlık aslında kişi ile devlet arasında karşılıklı hak, görev ve yükümlülük ilişkisi doğurur ${ }^{4}$. Bununla birlikte, bu ilişki bir sözleşme ilişkisi değildir. Devlet vatandaşlık bağının nasıl kurulacağını ve kaybedileceğini belirleme konusunda mahfuz yetkiye sahiptir ${ }^{5}$. Diğer bir anlatımla, devlet egemenlik hakkını kullanarak kime vatandaşlık verileceğine ya da kimin vatandaşlıktan çıkarılacağına kendisi karar verir 6 .

Vatandaşlık asli olarak doğum yoluyla kazanılır. Bu şekilde kazanılan vatandaşlıkta kişi ile devlet arasındaki bağlılı̆̆ın mevcut olduğu kabul edilmektedir ${ }^{7}$. Uluslararası uygulamada hemen hemen tüm devletler soy bağı (kan esas1- ius sanguinis), doğum yeri (toprak esas1-ius soli) veya bunların her ikisine bağlı olarak doğum yoluyla kişiye vatandaşlık hakkı tanımaktadır. Vatandaşlığın bu şekilde aslen kazanılması yoluna ilave olarak, devletler egemenlik haklarını kullanarak bazı kişilere sonradan vatandaşlık (ius nexi) hakkı tanıyabilir. Müktesep vatandaşlık olarak da anılan bu müessese ile devletler olağan veya olağanüstü yoldan bazı kişilere vatandaşlık verebilmektedir. Olağan usulde devletler kendi topraklarında yaşayan ve ülke bağları bulanan yabancılara belirli koşullar dahilinde vatandaşlığa alınma imkânı tanıyabilmektedir ${ }^{8}$. Bu bağlamda devletler evlenme ve evlat edinilme gibi kişinin vatandaşlığına geçmek istediği ülke ile irtibatını sağlayan hukukî olaylara sonuç bağlayabildikleri gibi, genel bir yol olarak ülkede belli bir süre ikamet eden yabancılara dil bilme, milli güvenlik ve kamu düzeni bakımından tehlike oluşturmama gibi belli koşullar dahilinde vatandaşlığa geçme imkânı sağlayabilmektedir ${ }^{9}$.

Vatandaşlığın olağanüstü yolla kazanılmasında ise, devletler istisnai bazı hallerde takdir yetkilerini kullanarak ekonomi, spor, kültür, bilim ve sanat gibi alanlarda özel niteliği haiz yabancıları, olağan vatandaşlığa alınma yoluna kıyasla kolaylaştırılmış bir usulle vatandaşlığa alabilmektedir ${ }^{10}$. Bu yolla vatandaşlığa alınan yabancıların üstün vasıflarının ülkenin gelişmesi ve ilerlemesine katkıda bulanacağı düşünülmektedir. Hatta en iyi ve en parlak nitelikleri haiz bilim adamı, sporcu, girişimci ve sanatçıları kendi toplumlarına katma konusunda ABD, Kanada, $\mathrm{AB}$ ülkeleri, Çin, Rusya ve Singapur gibi pek çok ülke arasında bir yarışın olduğu bile ifade edilebilir ${ }^{11}$.

Bilim, kültür, sanat ve spor gibi alanlardaki üstün vasıfları nedeniyle oturma izni ve/veya vatandaşlık alan kişi sayısının görece az olması ve uygulamaların kişiye özgü olması nedeniyle konu literatürde tartışmaya neden olmamıştır. Benzer şekilde, ekonomik yatırımın yanı sıra yatırımcının girişimcilik ve iş kurma becerisi gibi nitelikleri göz önüne alınarak yetkili makamın takdiriyle istisnai nitelikte verilen oturum izni ve vatandaşlık uygulamaları da eleștiri konusu yapılmamıştır. Esasen, diğer istisnai vatandaşlık kazanma hallerinde olduğu gibi ekonomik katk1

${ }^{1}$ DOĞAN, Vahit: Türk Vatandaşlık Hukuku, 16.B (Tıpkı Basım), 2020, s.6; DZANKIC, Jelena, The Pros and Cons of Ius Pecuniae: Investor Citizenship in Comparative Perspective, EUI RSCAS, 2012/14, [GLOBALCIT], EUDO Citizenship Observatory, (Pros and Cons), s.1; GÖGER, Erdoğan: Türk Tabiiyet Hukuku, Sevinç Matbaası, 1979, s.6; TURAN, Turgut/TANRIBİLİR Feriha Bilge:Vatandaşl1k Hukuku, 4.B, 2017, s.25.; ÖZKAN, Işıl: "Vatandaşl1k Satılabilir Birşey midir?," Uluslararası Sanat Kültür ve İletişim Dergisi, 1(1), 2018, s.55.

${ }^{2}$ DOĞAN, s.1-2.

${ }^{3}$ ERDEM, B. Bahadır: Türk Vatandaşlık Hukuku, 7. Baskı, 2019, s.3-4.

${ }^{4}$ DZANKIC, Jelena: "Citizenship with a Price Tag: The Law and Ethics of Investor Citizenship Programmes", Northern Ireland Legal Quarterly 65(4), 2014, (Price Tag), s.387-388; AYBAY, Rona/ÖZBEK Nimet/ERSEN PERÇİN, Gizem: Vatandaşlik Hukuku, 2019, s.4.

${ }^{5}$ DZANKIC, Price Tag, s.388; GÜNGÖR, Gülin: Tabiiyet Hukuku, 8.B, 2020, s.13-14.

${ }^{6}$ DOĞAN, s.3; ERDEM, s.5; GÖGER, s.7; NOMER, Engin, Türk Vatandaşlık Hukuku, 27.B, 2020, s.5;

7 DZANKIC, Pros and Cons, s.1; YILMAZ, Alper Çağrı: "Mukayeseli Hukukta ve Türk Hukukunda Yatırımc1 Vatandaşlık Olgusu: Ius Pecuniae", Milletlerarası Hukuk ve Milletlerarası Özel Hukuk Bülteni 38 /1, 2018, s.192.

${ }^{8}$ European Commission, Commission Staff Working Document, Accompanying the Document Report From the Commission to the European Parliament, the Council, the European Economic and Social Committee and the Committee of the Regions, Investor Citizenship and Residence Schemes in the European Union, $\{$ COM(2019) 12 final $\}$, (Document) s.2.

${ }^{9}$ DZANKIC, Pros and Cons, s.1.

${ }^{10}$ European Commission, Document, s.2; SHACHAR, Ayelet/HIRSCHL, Ran: "On Citizenship, States, and Markets", The Journal of Political Philosophy, 22(2), 2014, s.231.

${ }^{11}$ SHACHAR/HIRSCHL, s.236-239. 
sağlamaya dayalı olarak vatandaşlık kazanan kişi sayısı da sınırlı kalmıştır.

Bununla birlikte, yatırımcının niteliğini önceleyen yatırım yoluyla vatandaşlık uygulamaları son 30 yılda boyut değiştirmiş ve pek çok ülke yatırımcının niteliğinden çok elde edilen mali kaynağı ön plana alan vatandaşlık programları kabul etmeye başlamıştır ${ }^{12}$. Yatırımcı programları olarak da adlandırılan bu uygulamalar önceleri küçük ada devletlerinde başlamış, özellikle 2008 krizi sonrasında, Avrupa ülkeleri de dahil olmak üzere daha geniş bir coğrafyaya yayılmıştır ${ }^{13}$. Türkiye de uluslararası gelişmelerden uzak kalmamış ve 2016 yılında yapmış olduğu mevzuat değişikliği ile ekonomik katkının ön planda tutulduğu yatırım yoluyla vatandaşlık kazanma uygulamasını hayata geçirmiştir.

Yatırımcı programlarının temelinde ekonomik kaynak yaratma, özellikle de küresel ekonomik krizlerin yaratmış olduğu olumsuzlukların varlıklı kişilerin ülkeye getirecekleri ekonomik katkılar ile azaltılması hedefi bulunmaktadır. Bununla birlikte, yatırımc1 programlarında, ekonomik katkının kişinin niteliğinin önüne geçmesi hatta tek koşul olarak aranması, uygulamaları uluslararası düzeyde tartış1ır hale getirmiştir. Eleştiriler güvenlik, vergi, seçme ve seçilme hakkı, askerlik yükümlülüğü ve ekonomik fayda başlıkları altında toplanabilir. Söz konusu eleştirilerin temelinde ise vatandaşlığın metalaştırılması ve aidiyet bağı tesis edilmeden vatandaşlığın verilmesi hususları yatmaktadır.

Bu çalışma dünya örnekleri ışığında yatırım yoluyla vatandaşlık uygulamalarına yöneltilen eleştirileri sistematik bir bakış açısıyla incelemeyi amaçlamaktadır. İncelemede ilk olarak yatırım yolu ile vatandaşlık kavramı ve tarihsel geçmişini de içerecek şekilde yatırım yolu ile vatandaşlık kazanılması yöntemleri ele alınacak, sonrasında ise Türkiye uygulamasına değinilecektir. Müteakiben yatırım yoluyla vatandaşlık uygulamalarına yöneltilen eleştiriler üzerinde durulacaktır. Çalışmanın sonuç bölümünde ise, yatırım yoluyla vatandaşlık kazanılması konusunda en uygun düzenlemenin nasıl olması gerektiği konusundaki kanaatimiz ortaya konulacaktır.

\section{YATIRIM YOLU ILE VATANDAŞLIK KAVRAMI ve YATIRIM YOLU ILE VATANDAŞLIK KAZANMA YÖNTEMLERİ}

\section{A. Yatırım Yoluyla Vatandaşlık Kavramı}

Yatırım yoluyla vatandaşlık kavramı en geniş anlamıyla yabancı kişinin ülkeye yaptığı doğrudan veya dolaylı yatırım veyahut bağış karşıllığında, yatırım yapılan devlet tarafından verilen vatandaşlık olarak tanımlanabilir ${ }^{14}$. Hangi tür yatırımlar karşılığında vatandaşlık verileceği ve vatandaşlığın verilmesi konusunda yatırımcının niteliğinin ne ölçüde dikkate alınacağı, bu konuda mahfuz yetkiye sahip devlet tarafından belirlenecektir. Ülkeler ihtiyaçları doğrultusunda yatırımcının aktif bir tutum sergileyerek ülkede sanayi yatırımı yapmasını veya istihdam oluşturan faaliyetlerde bulunmasını şart koşabilir ${ }^{15}$. Bazı ülkeler ise yatırımcının pasif olarak yalnızca belli bir sermayeyi doğrudan para olarak bankaya yatırma, belli bir devlet fonuna bağışlama, devlet tahviline bağlama veya gayri menkul satın alma şeklinde ülkeye getirmesini yeterli sayabilir ${ }^{16}$. Aktif yatırımın arandığ 1 durumlarda yatırımcının girişimcilik ve organizasyon yeteneği gibi nitelikleri, pasif yatırım halinde ise ekonomik katkı ön plandadır. Bu bağlamda yatırım yoluyla vatandaşlık uygulaması, kişinin niteliğini veya getirilen ekonomik katkıyı öncelemesine göre iki yöntem temelinde tatbik edilebilir.

\section{B. Yatırım Yoluyla Vatandașlık Kazanma Yöntemleri}

\section{Kişinin Niteliğinin Ön Planda Tutulduğu Vatandaşlık Kazanma Uygulamaları}

Geleneksel olan ilk yöntemde kişinin ülkeye belli bir ekonomik katkı getirmesine ilave olarak, bu sermayeyi girişimcilik, sanayi tesisi kurma veya istihdam yaratma gibi vasıfları ile birleştirerek vatandaşlığına geçmek istediği ülkenin hizmetine sunması aranmaktadır. Diğer bir anlatımla, vatandaşıı̆ga alınma için aktif bir yatırımın yapılması gereklidir. Topluma yapılan bu fevkalade katkının karşılı̆̆ında ise, devlet olağan yoldan vatandaşlığa alınma için öngörülen

${ }^{12}$ ADIM, Leila: Between Benefit and Abuse: Immigrant Investment Programs, 62 St. Louis U. L.J., 2017, (Investment), s.121.

${ }^{13}$ SOLIMANO, Andrés: Investment Migration, Economic Development and the UN Sustainable Development Goals, Investment Migration Council, and International Centre for Globalisation and Development, 2020, s.6.

${ }^{14}$ SHACHAR, Ayelet: "Citizenship for Sale?, in Shachar, Ayelet/Bauböck Rainer/Bloemraad, Irene/Vink, Maarten, (ed.) Oxford Handbook of Citizenship, Oxford University Press, 2017, (Citizenship for Sale) s.790.

${ }^{15}$ ADIM, Investment, s.122

${ }^{16}$ ADIM, Investment, s.122 
birtakım şartları aramamakta veya yumuşatarak uygulamaktadır ${ }^{17}$. Örneğin olağan yoldan vatandaşlık kazanmak için gerekli olan dil bilme veya ülkede belli bir süre ikamet etme koşulları aranmayabilir $^{18}$. Uygulamanın gerisinde ise, teknolojik yatırımların artırılmas1, ihracat ve istihdam olanaklarının geliştirilmesi ve geri kalmış bölgelerin kalkındırılması gibi ekonomik hedefler yanında topyekûn olarak toplumsal gelişmeye ivme kazandırılması amacı yatmaktadır. Ekonomik ve toplumsal gelişme; ekonomik sermaye yanında, ekonomik sermayeyi değere dönüştürebilecek nitelikli insan kaynağının varlığı ile yakından ilgilidir. Ekonomik sermaye ve nitelikli insan kaynăgından yoksun olan veya daha fazla ekonomik sermaye ve vasıflı insan arayışında olan pek çok devlet sermaye sahibi nitelikli yabancılara kapılarını açmaktadır. Hemen belirtmek gerekir ki; bu yöntem istisnai niteliktedir ve vatandaşlığa alınacak kişinin üstün vasfi getirdiği sermayeden daha önemlidir. Devletler vatandaşlık konusunda sahip oldukları mahfuz yetkilerini kullanarak sınırlı sayıda özel vasıfları haiz kişilere bu olanağı sunmaktadır ${ }^{19}$. Getirilecek ekonomik katkının niteliği ve kime vatandaşlık verileceği konularında ise yetkili makamın geniş bir takdir yetkisi bulunmaktadır ${ }^{20}$.

Bu yöntem tatbik edilerek vatandaşlığa alınma istisnai nitelikte olmakla birlikte, yöntemin uluslararası alandaki uygulaması yaygındır ${ }^{21}$. Nitekim, bilim, kültür, ekonomi, sanat ve spor gibi alanlarda üstün vasıfları olan kişilere vatandaşlık tanınması dünyanın pek çok ülkesinde öteden beri uygulanmaktadır. Bu bağlamda Almanya ve Fransa gibi ülkeler de dahil olmak üzere $22 \mathrm{AB}$ üyesi ülke mevzuatında ilgili ülke için olağanüstü hizmeti geçmiş kişilere vatandaşlık verileceği öngörülmektedir ${ }^{22}$. Olağanüstü hizmetin ekonomik katkıyı da kapsadığı konusunda duraksama yoktur ${ }^{23}$. Nitekim mevzuatlarında olağanüstü hizmetin geçeceği alanları örnekleme yoluyla sayan Avusturya, Slovenya, Slovakya ve Bulgaristan bilim, teknoloji, sanat ve kültür alanlarına ilave olarak ekonomi ve ticaret alanına da vurgu yapmıştır.

Konunun daha net anlaşılması bakımından olağan yoldan vatandaşlığın kazanılmasının en zor olduğu ülkelerden biri olan Avusturya uygulamasına yakından bakılmasında fayda bulunmaktadır ${ }^{24}$. Avusturya ülkeye en az 3 milyon Euro tutarında yatırım yapan kişileri, olağan yoldan vatandaşlık kazanılması için aranan iyi derecede Almanca bilme, ülkede kesintisiz 10 yıl ikamet etme ve eski vatandaşlığı terk etme şartlarına tabi tutmaksızın doğrudan vatandaşlığa alabilmektedir ${ }^{25}$. Bununla birlikte, yatırımın ortak girişim yoluyla veya doğrudan istihdam veya yeni ihracat alanları yaratan bir işletmeye getirilmesi şart koşulmaktadır. Getirilen yatırımdan ziyade kişinin niteliğinin ön planda tutulduğu uygulama kapsamında Avusturya devletinin kişi hakkındaki incelemesi genel olarak 24 ilâ 36 ay sürmekte ve çok sınırlı sayıda insana vatandaşlık verilmektedir ${ }^{26}$. Gerçekten de 2014-2018 yılları arasında ekonomi de dahil olmak üzere bilim, teknoloji, sanat ve kültür alanlarında olağanüstü hizmeti nedeniyle sadece 139 yabancı Avusturya vatandaşlığını kazanabilmiştir ${ }^{27}$.

\section{Ekonomik Katkının Ön Planda Olduğu Tutulduğu Vatandaşlık Kazanma Uygulamaları} (Yatırımc1 Programları)

Yatırım yoluyla vatandaşlık kazanılması konusundaki ikinci yöntemde devletler ülkeye belli bir ekonomik kaynağı getiren kişileri doğrudan veya belli süre ikamet şartına bağlı olarak vatandaşlığa almaktadır. İlk yöntemden farklı olarak bu yöntemde vatandaşlığa alınacak kişinin

\footnotetext{
${ }^{17}$ European Commission, Document, s.3.

18 BAUBÖCK, Rainer/WALLACE GOODMAN, Sara: Naturalisation, EUDO Citizenship, Policy Brief No.2, s.7 https://cadmus.eui.eu/bitstream/handle/1814/51625/RSCAS_EUDO_CIT_PB_2011_02.pdf?sequence=1 (Erişim Tarihi: 15.10.2020); DZANKIC, Pros and Cons, s.7.

19 BAUBÖCK/WALLACE GOODMAN, s.7; DZANKIC, Jelena: Investment-based Citizenship and Residence Programmes in the EU, EUI RSCAS, 2015/08, [GLOBALCIT], EUDO Citizenship Observatory, (Citizenship), s.5.

${ }^{20}$ European Commission, Document, s.3; ŞiT KÖŞGEROĞLU, Banu: "İstisnai Yoldan Vatandaşlı̆̆ın Kazanılmasına İlişkin Genel Esaslar ve Son Değişiklikler Çerçevesinde Türk Vatandaşlığının İstisnai Yoldan Kazanılması”, Hacettepe Hukuk Fakültesi Dergisi, 7(1), 2017, s.181.

${ }^{21}$ BARAN ÇELIKK, Neşe: “Güncel Gelişmeler Işı̆̆ında Türk Vatandaşlığının İstisnai Haller Kapsamında Kazanılması”, Türkiye Barolar Birliği Dergisi 130, 2017, s.365; DZANKIC, Pros and Cons, s.7.

${ }^{22}$ DZANKIC, Citizenship, s.6-7.

${ }^{23}$ DZANKIC, Citizenship, s.8.

${ }^{24}$ STILLER, Martin: Pathways to Citizenship for Foreigners in Austria, International Organization for Migration, 2020, s.9.

${ }^{25}$ DZANKIC, Pros and Cons, s.11; STILLER, s.58.

26 Henley\&Partners: “Austria Citizenship-by-Investment Factsheet”, https://www.henleyglobal.com/citizenshipaustria/ (Erişim Tarihi: 25.10.2020)

${ }^{27}$ STILLER, s.57.
} 
niteliğinden ziyade, ülkeye getirmiş olduğu ekonomik katkı ön planda tutulmaktadır ${ }^{28}$. Ekonomik katkının vatandaşlığa alınacak kişinin niteliğinin önüne geçmesi sebebiyle bu yöntemi konu alan vatandaşlık uygulamaları literatürde ius pecuniae ${ }^{29}$ kavramı ile anılmaya başlanmıştır. Kavram Türkçe'ye paranın hukuku olarak çevrilebilir. Vatandaşlık hukuku bağlamında ius pecuniae kavramı ulusal ve uluslararası literatürde yabancının ülkeye belli bir ekonomik katkı getirmesi şartına bağlı olarak verilen vatandaşlığı tanımlamak üzere kullanılmaktadır ${ }^{30}$.

Salt ekonomik katkı karşılığında vatandaşlık verilmesi son 30 yıla mahsus bir uygulamadır $^{31}$. Bununla birlikte, uygulamanın kişinin vasfinın önem arz ettiği yatırım yoluyla vatandaşlık uygulamalarının önüne geçtĭgi, hatta yatırım yoluyla vatandaşlık uygulaması denildiğinde sadece ekonomik katkının ön planda olduğu uygulamaların akla geldiği vurgulanmalıdır. $\mathrm{Bu}$ yöntem temelinde tatbik edilen vatandaşlık politikaları uygulamada ekonomik vatandaşlık programı, göçmen yatırımcı programı, yatırımcı programı, yatırım yoluyla vatandaşlık programı gibi isimlerle ${ }^{32}$, bu programlar neticesinde verilen vatandaşl1k ise ekonomik vatandaşlık, yatırımcı vatandaşlığ vatandaşlık gibi farklı adlarla anılmaktadır ${ }^{33}$. Bu çalışmada devletlerin ekonomik katkı temelinde uyguladıkları vatandaşlık politikaları "yatırımcı programları", bu yöndeki politikalar neticesinde elde edilen vatandaşlık ise "yatırım yoluyla vatandaşlık" 34 kavramı ile ifade edilecektir.

Yatırımcı programları kapsamında verilen vatandaşlık, devletin yatırımcının ülkede belli bir süre ikametini arayıp aramamasına göre uygulamada iki şekilde tatbik edilmektedir. İkamet şartı aramayan, diğer bir anlatımla ekonomik katkı karşılığında kişiye vatandaşlık hakkı tanıyan programlar altın pasaport (golden passport), kişiye yapmış olduğu yatırım karşılığında ikamet izni veren programlar ise altın vize ( golden visa) programları olarak da adlandırılmaktadır. Birçok devlet kişinin yatırımı sonrasında öncelikle ülkede belli bir süre ikamet etmesini aramakta, sonrasında ise olağan veya kolaylaştırılmış bir usul çerçevesinde vatandaşlığa başvurmasına imkân tanımaktadır ${ }^{35}$.

a) İkamet Şartına Bağlı Olmaksızın Doğrudan Vatandaşlık Kazanılmasına Olanak Sağlayan Yatırımcı Programları

İkamet şartı aramayan yatırımcı programları, yatırımcının ülkede belli bir süre oturmasını aramamakta, milli güvenlik açısından tehdit oluşturmayan ve cezai açıdan temiz bir geçmişe sahip olan yatırımcıya ülkeye getirdiği belli bir mali kaynak karşıllğında doğrudan vatandaşlık kazanabilme olanağı tanımaktadır. Bu tür programlara başvuran yatırımcıların da genel olarak ülkede ikamet etme eğilimi olmamaktadır ${ }^{36}$. Yatırımcılar tarafindan programların tercih nedeni ilgili ülkenin pasaportuna kavuşmak, vize uygulamalarından muaf olarak dünyanın çeşitli ülkelerine seyahat etmek, vatandaşı olduğu ülkede oluşabilecek bir istikrarsızlı durumunda güvenli bir limana kolaylıkla erişim imkanına sahip olmak veya vergisel avantajlardan yararlanmak şeklinde tezahür etmektedir ${ }^{37}$.

$\mathrm{Bu}$ yöntemle vatandaşlık verilmesi uygulaması ilk olarak 1980'li yılların sonuna doğru

\footnotetext{
${ }^{28}$ ADIM, Investment, s.121; GÖLCÜKLÜ, İlyas: “Güncel Gelişmeler Işı̆̆ında Yatırım Yoluyla Türk Vatandaşlığının Kazanılması: Problemler ve Çözüm Önerileri”, Public and Private International Law Bulletin 40(1), 2020, s.139.

${ }^{29}$ Ius pecuniae kavramının doktrinde ilk kez Joachim Stern tarafından Avusturya vatandaşlık başvuruları için ödenmesi gereken bürokratik ücretlerdeki artışa dikkat çekmek için kullanıldığı ve zaman içerisinde ise ekonomik katkının ön planda tutulduğu yatırımcı programları bakımından kullanıldığı konusunda bkz. DZANKIC, Pros and Cons, s.1; YILMAZ, s.192-193.

${ }^{30}$ ANDRIOPOULOU, Athanasia: The "ius pecuniae": The Prize of Citizenship, BRIDGE Network - Working Paper 4, 2020, s.4; DZANKIC, Pros and Cons, s.1, YILMAZ. s.192-193.

${ }^{31}$ DZANKIC, Pros and Cons, s.9-10; SUMPTION, Madeleine/HOOPER, Kate: Selling Visas and Citizenship: Policy Questions from the Global Boom in Investor Immigration. Washington, DC: Migration Policy Institute, 2014, s.2.

${ }^{32}$ SCHERRER, Amandine/THIRION, Elodie: Citizenship by Investment (CBI) and Residency by Investment (RBI) Schemes in the EU State of Play, Issues and Impacts, European Parliamentary Research Service, 2018, s.11.

${ }^{33}$ NOMER, s.92.

${ }^{34}$ Yatırım yoluyla elde edilen vatandaşlık, gerek kişinin niteliğinin gerek ekonomik katkının ön planda tutulduğu uygulamaları kapsamaktadır. Her iki uygulamanın da özünde yatırım bulunmakta, buna mukabil birinde yatırımcının niteliği, diğerinde ise ekonomik katkı ön planda tutulmaktadır. Bu bağlamda yatırım yoluyla vatandaşlık üst kavram olup her iki uygulama şeklini de kapsamaktadır.

${ }^{35}$ DZANKIC, Pros and Cons, s.3.

${ }^{36}$ SURAK, Kristin: Global Citizenship 2.0 The Growth of Citizenship by Investment Programs, Investment Migration Working Papers IMC-RP2016/3, 2016, (Citizenship), s.5.

${ }^{37}$ SURAK, Kristin: "Millionaire Mobility and the Sale of Citizenship", Journal of Ethnic and Migration Studies, 2020, (Mobility), s.10-15; XU, Xin/EL-ASHRAM, Ahmed/GOLD, Judith: Too Much of a Good Thing? Prudent Management of Inflows under Economic Citizenship Programs, IMF Working Paper, Western Hemisphere Department, 2015, s.3.
} 
Karayip bölgesinde bulunan St. Kitts ve Nevis, Antigua ve Barbuda ve Dominika gibi küçük ada devletlerinde ortaya çıkmıştır. Bu devletler 100.000 ile 250.000 Dolar arasında değişen miktarlarda yatırım yapan, gayrimenkul alan ya da devlet bütçesinde bağışta bulunan yatırımcılara ikamet şartsız veya gerçekte ikamet sayılmayan kısa bir süre (beş yılda beş gün gibi) ülkede bulunma şartıyla vatandaşlık vermeye başlamışlardır ${ }^{38}$. Söz konusu ülkelerin yatırımcı programlarının temel cazibesini ise, bu devletlere ait pasaportlar ile Avrupa ülkelerine vizesiz giriş imkânı oluşturmuştur ${ }^{39}$.

Küçük ada devletleri ikamet şartsız yatırımcı programlarına ekonomik kaynak oluşturma düşüncesi ile başvurmaktadır. Bu ülkelerin ekonomileri çoğu kez turizm gibi belli bir sektöre veya şeker kamışı, muz ve kakao gibi belli bir tarım ürününe dayanır. Bu açıdan ekonomik yapıları kırılgandır. Ekonomik durumlarını iyileştirmek hedefiyle ülkelerinde ikamet etmeyecek veya yılın çok az bir günü ülkelerinde oturacak yabancılara vatandaşlık verilmesi, bu devletler bakımından mantıklı bir seçimdir. Bununla birlikte, vergi cennetleri olarak adlandırılan bu tür devletlerin yatırımcı programları kısa zaman içerisinde dolandırıcılık, yolsuzluk ve kara para aklama suçları ile ilişkilendirilerek itibarlarını yitirmiştir ${ }^{40}$.

İkamet şartsız yatırımcı programları 2008 yılı mali krizi sonrasında ise görece büyük devletler tarafından uygulanmaya başlanmıştır ${ }^{41}$. AB içerisinde ilk uygulama 2013 yılında Güney Kıbrıs Rum Yönetimi (GKRY) tarafından hayata geçirilmiştir. GKRY'yi Malta ve Bulgaristan izlemiştir. Anılan devletler mikro devletlere kıyasla daha yüksek miktarlarda yatırım karşılığında vatandaşlık vermeye başlamışlardır ${ }^{42}$. Vatandaşlık için GKRY 2,5 milyon, Bulgaristan 1 milyon, Malta ise 1,150.000 Euro'luk bir yatııımı şart koşmuştur ${ }^{43}$. Bu ülkeler tarafından yatırımın şekli konusunda ise yatırımcılara geniş bir yelpazede olanaklar sunulmuştur. Yatırımların ticaret şirketlerinden hisse satın alınması, finans kurumlarına mevduat olarak yatırılması, devlet tahviline veya gayrimenkul yatırım fonuna bağlanması gibi farklı şekillerde ülkeye getirilmesi yeterli sayılmıştır ${ }^{44}$.

$\mathrm{AB}$ ülkelerince uygulanan programlar mikro devletler tarafindan uygulanan yatırımc1 programlarının aksine daha fazla ilgi görmüştür. Zira $\mathrm{AB}$ ülkelerince uygulanan yatırımcı programları yalnızca ilgili ülkenin vatandaşlığını değil, aynı zamanda türev bir vatandaşlık olan $A B$ vatandaşlığını kazanma imkânı sunmaktadır. Nitekim AB'yi teşkil eden ülkelerin vatandaşları, aynı zamanda $A B$ vatandaşıdır. $A B$ vatandaşlığı ise kişilere $A B$ ülkelerinde serbest dolaşım ve ikamet hakkına ilave olarak, Avrupa Parlamentosu ve yerel seçimlerde oy verme ve aday olma hakkı gibi belli siyasî haklar tanımaktadır ${ }^{45}$. AB vatandaşlığı ayrıca üçüncü ülkelerde $\mathrm{AB}$ ülkelerinin diplomatik korumasından yararlanma olanağı vermektedir ${ }^{46}$. Bu itibarla $\mathrm{AB}$ vatandaşlığ GKRY, Malta ve Bulgaristan tarafından sunulan yatırımcı programlarının tercihinde üye ülke vatandaşlığından daha önemli bir fonksiyona sahip olmuştur ${ }^{47}$. Hatta bu ülkeler tarafından ekonomik katkı karşılığında sunulan vatandaşlığın, kendi vatandaşlıklarından ziyade $A B$ vatandaşlığı olduğunu söylemek yanıltıcı olmayacaktır ${ }^{48}$.

$\mathrm{AB}$ ülkelerinin kendi vatandaşlıklarının yanı sıra türev vatandaşlık olan $\mathrm{AB}$ vatandaşlı̆ğını ekonomik katkı temelinde yabancılara sağlaması, uygulamalar hakkında AB kurumları düzeyinde ciddi eleştirilerin gündeme gelmesine neden olmuştur ${ }^{49}$. İlginçtir ki; ekonomik katkı temelinde vatandaşlık verilmesi uygulaması ilk olarak GKRY tarafından başlatılmış olmakla birlikte, konu

\footnotetext{
${ }^{38}$ XU/EL-ASHRAM/GOLD, s.5.

${ }^{39}$ SURAK, Citizenship, s.24.

${ }^{40}$ SHACHAR, Citizenship for Sale, s.794.

${ }^{41}$ SOLIMANO, Andrés: Investment Migration, Economic Development and the UN Sustainable Development Goals, Investment Migration Council, and International Centre for Globalisation and Development, s.6.

${ }^{42}$ AB ülkeleri dışında; Karadağ, Ürdün ve Moldova gibi ülkelerde 100.000 Euro ile 1 Milyon Dolar arasında değişen miktarlarda yatırım yapan yabancılar, ikamet şartsız vatandaşlık alabilmektedir. Bununla birlikte, eski Tayland Başbakanı Taksin Shinawatra'nın yatırım yoluyla Karadağ vatandaşlı̆̆ını kazanması gibi örnekler, bu ülkeler tarafından uygulanan programların da güvenirliklerinin sorgulanmasına neden olmuştur. Bkz. DZANKIC, Pros and Cons, s.13-14.

${ }^{43}$ EU Commission, Document, s.3.

${ }^{44}$ DZANKIC, Citizenship, s.3;

${ }^{45}$ EU Commission, Document, s.2.

${ }^{46}$ BAUBÖCK, Rainer: What Is Wrong with Selling Citizenship? It Corrupts Democracy!, Debating Transformations of National Citizenship. IMISCOE Research Series Bauböck R. (ed), Springer, 2018, s.37

${ }^{47}$ DZANKIC, Citizenship, s.4; SCHERRER/THIRION, s.11.

${ }^{48}$ DZANKIC, Citizenship, s.2.

${ }^{49}$ BAUBÖCK, s.37; SCHERRER/THIRION, s.20.
} 
daha çok Malta uygulaması etrafında irdelenmiştir. Nitekim, 2014 yılında Avrupa Parlamentosu'nda "satılık vatandaşlık" başlığı ile açılan oturum sonucunda Malta'ya özel atıfta bulunularak, üye devletlerin salt ekonomik katkı temelinde uyguladıkları yatırımcı programlarını kınayan bir karar kabul edilmiştir ${ }^{50}$. Bahse konu ülkelere ilave olarak, genel olarak tüm $\mathrm{AB}$ ülkelerince uygulanan altın pasaport veya altın vize uygulamaları halihazırda doktrin, $\mathrm{AB}$ kurumları ve ulusal parlamentolar düzeyinde tartışılmaya devam etmektedir. Tartışmalar adalet, ayrımcılık yapmama ve samimi iş birliği ilkeleri yanında vergilendirme ve gerçek bir bağ kurulmadan verilen vatandaşlığın hukukiliği gibi konular etrafında cereyan etmektedir ${ }^{51}$.

b. İkamet Şartına Bağlı Olarak Vatandaşlık Kazanılmasına Olanak Sağlayan Yatırımcı Programları

İkamet şartlı yatırımcı programlarında yatırımcı ülkeye getirdiği mali kaynağın karşılığında öncelikle ilgili ülkede ikamet iznine sahip olmakta, sonrasında ise genel yoldan veya programda öngörülen süre ve şartlar temelinde vatandaşlığa başvurma imkanına kavuşmaktadır. Yatırımcılar açısından bu tür programlara başvurmanın birden çok gerekçesi olabilmektedir. Yeni bir ülkeye yerleşme, vizesiz seyahat, daha iyi bir eğitime erişim, siyasi istikrar ve vergisel avantajlar bu sebeplerin başında gelmektedir ${ }^{52}$. Yatırımcı programı uygulayan devletlerin en genel amacı ise, hiç şüphesiz ülkeye ekonomik kaynak sağlamaktır. Bu amacın yanı sıra gayrimenkul gibi zor durumda olan belli bir sektöre destek sağlamak, istihdam yaratmak, vergi gelirlerini artırmak, geri kalmış bölgeleri kalkındırmak, alt yapı yatırımları için kaynak yaratmak gibi çeşitli nedenler de yatırımc1 programlarının mesnedi olabilmektedir ${ }^{53}$.

İkamet şartlı yatırımcı programları, çoğunlukla ABD, İngiltere, Kanada Belçika, Avustralya, Portekiz, Yunanistan, İtalya ve Macaristan gibi nüfus ve coğrafi açıdan görece büyük ülkelerce uygulanmaktadır. Programlardan yararlanma ve sonrasında vatandaşlığa başvurma koşulları ise ilgili ülkenin yatırımcılar tarafından ne ölçüde tercih edildiği ile alakalı bir durumdur ${ }^{54}$. Yatırımcılar tarafından daha çok tercih edilen Birleşik Krallık, ABD ve İtalya gibi ülkeler daha kısıtlı sayıda yatırım opsiyonu sunarken, Portekiz ve Yunanistan gibi daha az tercih edilen ülkeler yatırımcılara yatırım tutarı ve çeşitliliği bakımından alternatifli olanaklar sunmaktadır. Vatandaşlığa alınma konusunda ise her ülke kendi koşulları çerçevesinde ikamet süresi içinde yatırımcı ile ülke arasında belli ölçüde aidiyet bağının tesisini amaçlamaktadır ${ }^{55}$. Bu bağın kurulması amacıyla Birleşik Krallık, ABD ve İtalya gibi devletler, yatırımcının ülkelerinde fiili ikametini şart koşarken, diğerleri yatırımcıya uzunca sayılabilecek bir süre sonunda vatandaşlığa başvurma imkânı tanımaktadır. Uygulamaları değerlendirmek bakımından aşağıda Birleşik Krallık, ABD, Portekiz ve Yunanistan örnekleri incelenecektir.

Birleşik Krallık 1994 yılından itibaren, 2 milyon Sterlini sermaye veya kredi sermayesi şeklinde Birleşik Krallık'ta kayıtlı ve aktif olarak faaliyette bulanan bir şirkete yatırım olarak getiren kişilere Tier-1 yatırımcı vizesi programı ile üç yıllık bir ikamet izni vermektedir ${ }^{56}$. İkamet izni müteakiben iki yıl daha uzatılabilmektedir. Kişinin getirmiş olduğu sermayeyi toplamda beş yıl süre ile ülkede tutması sonrasında ise, kendisi ve kendisine bağımlı aile üyeleri daimî ikamet iznine sahip olmaktadır. Öte yandan, Birleşik Krallık'ta 2011 yılında kabul edilen bir düzenleme ile 10 milyon Sterlin tutarında yatırım yapan kişilerin iki yılın sonunda, 5 milyon Sterlin tutarında yatırım yapan kişilerin ise üç yılın sonunda daimî ikamet izni almalarına olanak sağlanmıştır ${ }^{57}$. Yatırımcı ve bağımlı aile üyeleri daimî ikamet iznini aldıktan bir yıl sonra ise Birleşik Krallık vatandaşlığına başvurma imkânı elde etmektedirler. Bu kapsamda diğer vatandaşlığa alınma şartlarını taşımak koşuluyla yatırım tutarına göre kişi en erken üçüncü yılın sonunda, en geç ise altıncı yılın sonunda Birleşik Krallık vatandaşı olabilmektedir. Belirtilen süreler zarfında yatırımcının yılın 185 gününü Birleşik Krallık’ta geçirmesi gereklidir ${ }^{58}$.

Benzer bir uygulama ABD'de de bulunmaktadır. ABD 1990'lı yıllardan itibaren bu ülkede

50 European Parliament resolution of 16 January 2014 on EU citizenship for sale (2013/2995(RSP)), https://www.europarl.europa.eu/doceo/document/TA-7-2014-0038_EN.html (Erişim Tarihi: 16.10.2020)

${ }^{51}$ SCHERRER/THIRION, s. 20.

${ }^{52}$ SURAK, Citizenship, s.10.

${ }^{53}$ DZANKIC, Pros and Cons, s.3-4.

${ }^{54}$ SUMPTION/HOOPER, s.4.

${ }^{55}$ DZANKIC, Pros and Cons, s.3-4.

56 Henley\&Partners: Investment Migration Programs 2020, The Definitive Comparison of the Leading Global Residence and Citizenship Programs, 5th ed., 2020, s.83.

${ }^{57}$ YILMAZ, s.200.

${ }^{58}$ Henley\&Partners, s.83. 
en az 1 milyon Dolarlık yatırım yapan ve en az 10 kişilik istihdam oluşturan yabancılara EB-5 yatırımcı vizesi vermektedir. Yatırımcının ABD yönetimi tarafından belirlenen hedef bölgelerde yatırım yapması halinde ise yatırım tutarı 500.000 Dolar olarak saptanmıştır ${ }^{59} .2019$ yılında, yatırım miktarları sırasıyla 1,8 milyon ve 900.000 Dolara çıkarılmış, 10 kişiye istihdam oluşturma şartı ise korunmuştur ${ }^{60}$. Öngörülen meblağları yatırımc1 kendi kuracağ ABD'ye getirileceği gibi, ticari şirket, adi şirket ve ortak girişim gibi var olan ticari işletmeden hisse satın almak suretiyle de getirebilir ${ }^{61}$. Yatırımcı ayrıca ABD Vatandaşlık ve Göç Hizmetleri idaresi tarafindan onaylanan ve bölgesel merkez (regional center) olarak adlandırılan ticari girişimlere yatırım yaparak da program gereksinimlerini sağlayabilir. Bölgesel merkezler yoluyla yapılan yatırımda yatırımcı pasif konumunda kalmakta, 10 kişiye istihdam yaratma konusundaki yük merkezler tarafından yerine getirilmektedir. ABD'de istenilen yere yerleşme ve istenilen işte çalışma olanağını sağlaması nedeniyle, bölgesel merkez yolu yatırımcılarca daha çok tercih edilmektedir ${ }^{62}$. EB-5 yatırımcı vizesi ile yatırımc1, eşi ve 21 yaşından küçük evlenmemiş çocukları ile birlikte ilk iki yılı şartlı olmak üzere ABD'de daimî ikamete olanak sağlayan yeşil kart (green card) alabilmektedir ${ }^{63}$. Daimî ikamet iznine sahip yeşil kart sahibi ise başvuru tarihinden önceki son 30 ayda ABD'de fiili olarak ikamet etmek ve 5 ylllık ikamet süresinin kesintisiz olması şartıyla (bir yıldan fazla bir süre ABD dışında bulunmamak) vatandaşlığa başvurma olanağını elde etmektedir ${ }^{64}$.

Birleşik Krallık ve ABD'nin aksine, Portekiz tarafından uygulanan yatırımcı programından yararlanma ve vatandaşlık alma şartları daha esnektir. Buna göre 1 milyon ile 250.000 Euro arasında değişen miktarda bir meblağı bankalara mevduat olarak yatıran, şirketlerden hisse alan, gayrimenkul satın alan, bilim, sanat ve kültürün geliştirilmesi için bağışta bulunan veyahut en az 10 yeni istihdam oluşturan yatırımcı Portekiz'den ikamet izni alabilmektedir ${ }^{65}$. İkamet izni bir yıl süreyle verilmekte olup, müteakiben iki yıllık dönemler halinde beş yıla kadar uzatılabilmektedir. Beş yıllık dönem zarfında Portekiz'de fiili ikamet şart olmayıp, yatırımcının ilk yıl yedi gün, iki yıllık uzatma dönemlerinde ise 14 gün Portekiz'de bulunması yeterli bulunmaktadır ${ }^{66}$. Beş yılın sonunda yatırımcı temel düzeyde Portekizce bilmek, güvenlik açısından tehlike oluşturmamak ve vergi borcu olmamak kaydıyla Portekiz vatandaşlığına başvurabilmektedir. Portekiz'de benimsenen yatırıme programının benzeri Yunanistan tarafından da uygulanmaktadır. Yunanistan, 250.000 ilâ 800.000 Euroluk meblağı çeşitli yatırım araçları yoluyla ülkeye getiren kişilere beş y1llık ikamet izni vermektedir ${ }^{67}$. Söz konusu ikamet izni beşer yıllık dönemlerle uzatılabilmektedir. Yatırımcı yedinci yılın sonunda ise Yunanistan vatandaşlığına başvurabilmektedir.

Görüldüğü üzere, ikamet şartlı vatandaşlık uygulamaları Birleşik Krallık ve ABD gibi ülkelerde fiili ikamet ve süre şartlarına bağlanarak daha kısıtlayıcı bir şekilde uygulanmaktadır. $\mathrm{Bu}$ yolla bir yandan yabancının dil öğrenme ve çalışma gibi vasıtalarla toplumla entegrasyonunu sağlayacak bağların tesisi, diğer yandan ise yatırımcının ülkeye yerleşmesi neticesinde ödeyeceği vergiler ve yapacağ 1 harcamalar yoluyla yatırımın çarpan etkisinden yararlanılması amaçlanmıştır. Portekiz ve Yunanistan uygulamalarında ise fiili ikametin aranmaması nedeniyle yabancının ülke ile olan vatandaşlık bağının tesisi zorlaşmakta, yatırımın çarpan etkisinden yararlanma ise minimal düzeyde kalmaktadır.

\footnotetext{
${ }^{59}$ ADIM, Leila, Residence and Citizenship by Investment: An Updated Database on Immigrant Investor Programs, (Database) s.11 http://dx.doi.org/10.2139/ssrn.3474396, (Erişim Tarihi: 11.11.2020).

$60 \mathrm{https} / /$ travel.state.gov/content/travel/en/us-visas/immigrate/immigrant-investor-visas.html (Erişim Tarihi: 15.09.2020)

${ }^{61}$ United States Citizenship and Investment Services, https://www.uscis.gov/working-in-the-united-states/permanentworkers/employment-based-immigration-fifth-preference-eb-5/about-the-eb-5-visa-classification (Erişim Tarihi: 25.10.2020)

${ }^{62} \mathrm{https} / /$ travel.state.gov/content/dam/visas/Statistics/AnnualReports/FY2019AnnualReport/FY19AnnualReport-

TableVI-Part4.pdf (Erişim Tarihi: 25.10.2020)

${ }^{63}$ United States Citizenship and Investment Services, https://www.uscis.gov/working-in-the-united-states/permanentworkers/employment-based-immigration-fifth-preference-eb-5/eb-5-investors, (Erişim Tarihi: 25.10.2020)

${ }^{64}$ United States Citizenship and Investment Services, https://www.uscis.gov/policy-manual/volume-12-part-d-chapter-

3 (Erişim Tarihi: 26.10.2020)

${ }^{65}$ ADIM, Database, s.8.

${ }^{66}$ SHACHAR/HIRSCHL, s.245-246.

${ }^{67}$ https://www.enterprisegreece.gov.gr/en/greece-today/living-in-greece/residence-permits (Erişim Tarihi: 3.11 .2020 ) 


\section{YATIRIM YOLUYLA VATANDAŞLIK KAZANMA KONUSUNDA TÜRKIYYE UYGULAMASI}

Türkiye 1964 yılından itibaren özel niteliği haiz yatırımcıların vatandaşlığa alınmasına olanak sağlamaktadır ${ }^{68}$. Nitekim 1964 yılında yürürlüğe konulan 403 sayılı mülga Türk Vatandaşlığı Kanunu'nun (eTVK $)^{69} 7$ 'nci maddesinin d fikrası, Türkiye'ye sanayi tesisleri getiren veya ekonomik alanda olağanüstü hizmeti geçen ya da geçeceği düşünülen kişilere istisnaî yoldan vatandaşlık kazanma imkânı tanımıştır. Aynı hükme 5901 sayılı Türk Vatandaşlığı Kanunu'nun $(\mathrm{TVK})^{70} 12$ 'nci maddesinin 1-a fikrasında da yer verilmiştir. Bununla birlikte, gerek eTVK gerek 5901 sayılı TVK döneminde sanayi tesisi getirme veya ekonomik alanda olağanüstü hizmetten ne anlaşılması gerektiğine dair bir açık bir düzenlemeye yer verilmemiştir ${ }^{71}$. Dolayısıyla, sanayi tesisi getirme ve ekonomik alanda yapılan hizmetin türü ve niteliğini değerlendirme konusu yetkili makamın takdirine bırakılmıştır ${ }^{72}$. Ancak 5901 sayılı TVK'nın 12'inci maddesinde ekonomik alandaki hizmetin "olağanüstü" kelimesi ile nitelendirilmesi, "sanayi tesisi getirme" işinin ise bizatihi kendisinin büyük ölçekli yatırıma işaret etmesi nedeniyle, bu hükme dayanılarak verilecek vatandaşlığın objektif olarak ölçülebilir veya en azından somut olarak ortaya konulabilecek bir veriye dayanması gerektiği sonucuna ulaşılmaktadır ${ }^{73}$. Öte yandan, anılan yoldan vatandaşlığın kazanılması için ilgili bakanlığın bu yönde Cumhurbaşkanı'na gerekçeli teklifte bulunması gereklidir ${ }^{74}$. Doğası gereği anılan teklifte kişinin olağan yoldan vatandaşlığa alınma için aranan şartlara tabi tutulmaksızın istisnai yoldan vatandaşlığa alınması için geçerli objektif somut verilerin ortaya konulması zaruridir ${ }^{75}$.

Ayrıca, 5901 sayılı Kanun'un genel gerekçesinde “Türkiye'nin ekonomik ve sosyal hayatına katkıda bulunabilecek yabancılara Türk vatandaşlığının kolaylaştırılmış yoldan verilmesi suretiyle bunların ülkeye kazandırılmasının önemine" dikkat çekilmiştir ${ }^{76}$. İki farklı vurguyu içeren bu ifade de ekonomik katkıya dayalı olarak Türk vatandaşlığını kazanma eşiğinin yüksek tutulduğunu, buna karşılık vatandaşlığa alınma usulünün kolaylaştırılmış olduğunu göstermektedir ${ }^{77}$. Vurgulardan ilki Türkiye'nin ekonomik ve sosyal hayatına yapılacak katkıya yöneliktir. Bu bağlamda getirilecek sanayi tesisi veya yapılacak ekonomik katkı Türkiye'nin ekonomik hayatını ileriye götürecek, vergi geliri sağlayacak veya istihdam oluşturacak düzeyde olmalıdır. İkinci vurgu vatandaşlık verilmesi düşünülen yabancının vasfina yöneliktir. Dolayısıyla, hükmün yalnızca ülkeye gelecek ekonomik katkı ile ilgilenmediği, sanayi tesisi getirme veya ekonomik katk1 oluşturma niteliğini haiz kişileri aradığı söylenebilir. Ayrıca, hükmün ülkeye geçmişte olağanüstü ekonomik hizmeti geçenler yanında "olağanüstü hizmeti geçeceği düşünülen" kişileri de kapsaması, vurgunun tek başına ekonomik katkıya olmadığını, bunun ötesinde vatandaşlığa alınacak yabancının vasfının da önem arz ettiğini göstermektedir. Fiiliyatta da bu yoldan Türk vatandaşlığını kazanan kişi sayısı az olmuştur. 2009-2017 yılları arasında Türkiye'ye sanayi tesisleri getiren veya ülkeye ekonomik alanda olağanüstü hizmeti geçen 1226 kişi TVK m.12/a kapsamında istisnai yoldan Türk vatandaşlığını kazanmıştır ${ }^{78}$. Rakamlar Avusturya verileri ile kıyaslandığında görece yüksek görünmekle birlikte, yine de sinirlidir.

Öte yandan, kişinin niteliğinin ön planda tutulduğu vatandaşlık kazanma uygulamasına ilave olarak, 5901 say1l TVK'nın 12/1'inci maddesine, 28.07.2016 tarihli 6735 sayılı Uluslararas1

\footnotetext{
6823 Mayıs 1928 tarih ve 1312 sayılı Türk Vatandaşlı̆̆ı Kanunu'nun 6'ncı maddesi yabancıların istisnai yoldan vatandaşlık kazanmasına olanak sağlasa da; anılan hükmün ekonomik katkıyı kapsayıp kapsamadığı konusunda bir ayrıntıyı içermemesi nedeniyle, yatırım yoluyla vatandaşlık konusunda 403 sayılı eTVK başlangıç noktası olarak kabul edilmiştir.

${ }^{69}$ RG: $22 / 02 / 1964 ; 11638$.

${ }^{70}$ RG: $12 / 6 / 2009 ; 27256$

${ }^{71}$ GÜNGÖR, s.102; YILMAZ, s.207.

72 GÖGER, s.82; NOMER, s.90

${ }^{73}$ GÜNGÖR, s. 102.

${ }^{74}$ ERDEM, s.139; GÜNGÖR, s.102.

${ }^{75}$ DOĞAN, s.77.

${ }^{76}$ Genel Gerekçe, TVK'nın tümüne şamil bir anlayışı ortaya koymakla birlikte, Kanunun ilk kabul edildiği halinde 12/1(b) hükmünün bulunmadığı not edilmelidir. Bu nedenle Genel Gerekçe'deki bu ifadenin TVK m.12/1(a) bakımından geçerli olduğunun kabulü gerekir.

77 TURAN/TANRIBİLİ, s.84-85.

781964 yılında yürürlüğe giren 403 sayılı TVK döneminden 2017 yılına kadar istisnai yoldan Türk Vatandaşlığını kazanan kişi sayısı konusunda istatistiki bilgiler için Bkz. ŞİT KÖŞGEROĞLU, s.176-178.
} 
İşü̈cü Kanunu'nun (UIKK) ${ }^{79} 27$ 'inci maddesi ile eklenen yeni (b) bendi ile salt ekonomik katkıya dayalı vatandaşlık verilmesinin de önü açılmıştır. TVK'nın 12/1(b) maddesine göre “4/4/2013 tarihli ve 6458 sayll Yabancilar ve Uluslararast Koruma Kanununun 31 inci maddesinin birinci fikrasının (j) bendi uyarınca ikamet izni alanlar ... ve bunların yabancı eşi, kendisinin ve eşinin ergin olmayan veya bağıml yabancı çocuğu" istisnai yoldan Türk vatandaşlığına kazanabilecektir. Yabancılar ve Uluslararas1 Koruma Kanunu'nun (YUKK) ${ }^{80} 31 / 1(\mathrm{j})$ maddesi ise “Türkiye'de çalışmayan ancak Cumhurbaşkanınca belirlenecek kapsam ve tutarda yatırım yapacaklar ile bunların yabancı eşi, kendisinin ve eşinin ergin olmayan veya bağıml yabancı çocuğu"na kısa dönem ikamet izni verilebileceğini hükme bağlamaktadır. TVK 12/1(b) ve YUKK'nın 31/1(j) maddeleri birlikte değerlendirildiğinde, Cumhurbaşkanınca belirlenecek kapsam ve tutarda yatırım yaparak kısa dönem ikamet izni alan kişinin, kendisi ile birlikte yabancı eşinin, kendisinin ve eşinin ergin olmayan veya bağımlı yabancı çocuğunun Türk vatandaşlığını istisnai yoldan kazanabileceği anlaşılmaktadır. Yapılacak yatırımın türü, miktarı ve süresi ise Türk Vatandaşlığı Kanununun Uygulanmasına İlişkin Yönetmelik (TVKUY) ${ }^{81}$ de $2017^{82}$ ve $2018^{83}$ yıllarında yapılan değişiklikler ile düzenlenmiştir. Belirtilen değişiklikler sonrası TVKUY'nin 20'inci maddesinin ilgili kısmı aşağıdaki gibidir:

(2) Aşağıdaki şartlardan herhangi birini sağlayan yabancl, Kanunun 12 nci maddesinin birinci fikrasının (b) bendi kapsamında Cumhurbaşkanı kararı ile Türk vatandaşlığını kazanabilir:

a) En az 500.000 Amerikan Doları veya karşıllğ̆ döviz ya da karşıllğ̆ Türk Lirası tutarında sabit sermaye yatırımı gerçekleştirdiği Sanayi ve Teknoloji Bakanlı̆̆ınca tespit edilen,

b) En az 250.000 Amerikan Dolarl veya karşıllı̆̆ döviz ya da karşılığı Türk Lirası tutarında taşınmazı tapu kayıtlarına üç yll satılmaması şerhi koyulmak şartıyla satın aldığı veya kat mülkiyeti ya da kat irtifakı kurulmuş, en az 250.000 Amerikan Doları veya karşılığı döviz ya da karşıllğı Türk Lirası tutarı peşin olarak yatırılan taşınmazın satışının vaat edildiğine dair noterden düzenlenen sözleşmenin ü̧̧ yıl süreyle devri ve terkini yapılmayacağ taahhüdüyle tapu siciline şerh edildiği Çevre ve Şehircilik Bakanlı̆̆ınca tespit edilen,

c) En az 50 kişilik istihdam oluşturduğu Aile, Çalışma ve Sosyal Hizmetler Bakanlığınca tespit edilen,

c) En az 500.000 Amerikan Doları veya karşıllı̆̆ döviz ya da karşıll ğg Türk Lirası tutarında mevduatı üç yll tutma şarttyla Türkiye'de faaliyet gösteren bankalara yatırdı̆̆g Bankacllık Düzenleme ve Denetleme Kurumunca tespit edilen,

d) En az 500.000 Amerikan Doları veya karşıllı̆̆ döviz ya da karşıllğ̆ Türk Lirası tutarında Devlet borçlanma araçlarını ǚç yll tutmak şartıyla satın aldığı Hazine ve Maliye Bakanlığınca tespit edilen.

e) En az 500.000 Amerikan Doları veya karşılı̆̆ı döviz ya da karşılı̆̆ Türk Lirası tutarında gayrimenkul yatırım fonu katılma payı veya girişim sermayesi yatırım fonu katılma payın en az üç yll elinde tutma şartıyla satın aldığ Sermaye Piyasası Kurulunca tespit edilen ${ }^{84}$.

Görüldüğü üzere TVKUY'de yabancının kısa dönem ikamet izni (maksimum beş yıl) aldıktan sonra hangi andan itibaren vatandaşlığa başvurabileceği konusunda açık bir düzenleme bulunmamaktadır. Bununla birlikte, TVKUY m. 20(2)'nin yatırım yapılmasının akabinde vatandaşlığa başvurmaya imkân verecek şekilde kaleme alındığını değerlendirmekteyiz ${ }^{85}$. Bu bağlamda, TVKUY m. 20(2)'nin (a) ve (c) bentleri kapsamında "sabit sermaye yatırımı" veya "istihdama yönelik yatırım" yapan yatırımcılar, söz konusu yatırımlarını ilgili Bakanlık marifetiyle belgelediklerinde; (b), (ç), (d) ve (e) bentleri kapsamındaki yatırımcılar ise, öngörülen meblağları üç yıl süreyle tutmak şartıyla belirtilen yatırım araçlarına yatırdıklarını ilgili kurumca tespit ettirdikten sonra, önce kısa dönem ikamet iznine, akabinde de vatandaşlığa başvurabileceklerdir. Şüphesiz ikamet izninin alınması sonrasında vatandaşlığa alınma için ilgilinin kamu düzeni ve milli güvenlik bakımından engel halinin olup olmadığı araştırılacak ve ancak durumu uygun bulunanlar, bu konuda takdir yetkisine sahip Cumhurbaşkanı kararı ile

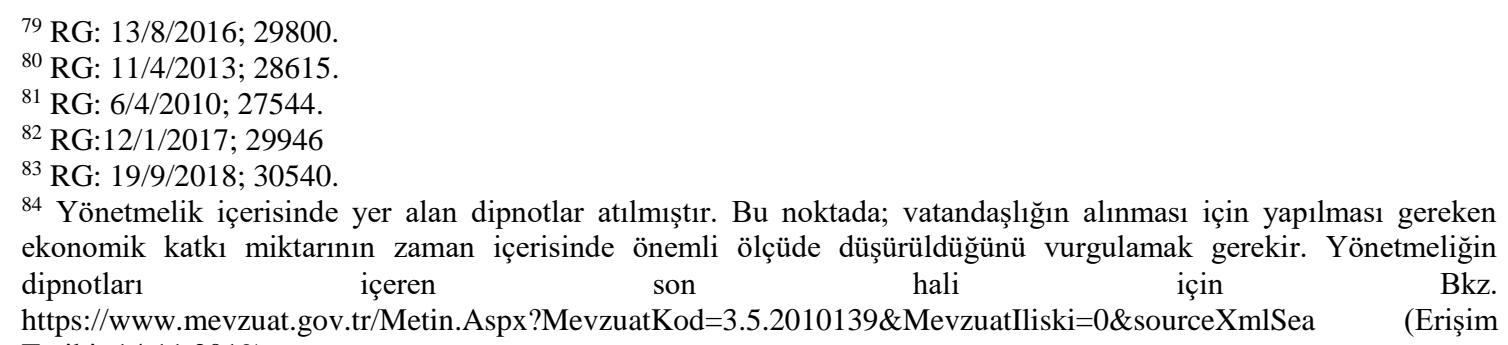
Tarihi: 14.11.2019).

${ }^{85}$ Aksi yönde görüş için bkz. YILMAZ, s.211. 
vatandaşlığa alınacaktır. Bu halde vatandaşlığa başvurmak için ikamet iznine sahip olmak ön şart olmakla birlikte, başvuru için yatırımın elde tutulması için öngörülen üç yıllık sürenin dolması beklenmeyecektir. Bu anlamda ülkemiz uygulamasının ikamet şartlı yatırımcı programı olmakla birlikte, fiili olarak ikamet şartsız yatırımcı programları gibi tatbik edildiği değerlendirilmektedir. Kişinin öngörülen yatırım süresi içinde yatırım konusundaki şartları gerçekleştirmemesi halinde ise vatandaşlığın geri alınması mümkün olabilecektir.

\section{YATIRIM YOLUYLA VATANDASLIK KAZANMA UYGULAMASINA YÖNELTILEN ELEŞTIRILER VE TÜRKIYYE UYGULAMASI BAKIMINDAN GEÇERLILIIKLERİ}

\section{A. Genel Olarak}

Yatırım yoluyla vatandaşlık uygulaması ulusal ve uluslararası doktrinde ayrımcılık yapmama, adalet, eşitlik, hakkaniyet gibi bazı etik ilke ve kavramlar çerçevesinde ciddi eleştirilere konu olmuştur. Gerçekten de dünyanın pek çok yerinde yaşanan savaş, siyasi ve ekonomik istikrarsızlık gibi gerekçelerle, daha iyi bir yaşam kurmak amacıyla başka ülkelere göç etmek zorunda kalan göçmenlerin, $\mathrm{ABD}$ ve $\mathrm{AB}$ ülkeleri başta olmak üzere pek çok ülkeye giriş yapmasına dahi izin verilmemektedir ${ }^{86}$. Bu ülkelere giriş yapabilen yabancılar sıkı sınır kontrollerine ve göçmenlik yasalarına tabi tutulmakta, vatandaşlık almaları ise ülkenin dilini bilme, uzun dönem ikamet izni sahibi olma hatta sahip olduğu vatandaşlıktan çıkma gibi şartlarla zorlaştırılmaktadır ${ }^{87}$. Buna mukabil belli bir maddi varlığa sahip olan kişiler, bu maddi varlığ pasif olarak ülkeye getirmeleri karşılığında aileleri ile birlikte ayrıcalıklı bir muamele çerçevesinde ikamet izni ve/veya vatandaşlık alabilmektedir ${ }^{88}$.

$\mathrm{Bu}$ durum ahlakî ve felsefi açıdan tartış1labilir olmakla birlikte, devletlerin vatandaşlık verme konusunda mahfuz yetkiye sahip olmaları karşısında, ahlaki ve felsefi eleştirilerin hukuksal bir değeri bulunmamaktadır. Ancak ahlaki ve felsefi tartışmaların ötesinde yatırım yoluyla vatandaşlık uygulamalarının hukuki, sosyal ve siyasi bazı sorunları beraberinde getirmesi muhtemeldir ${ }^{89}$. Bu sorunların temelinde ise kişi ile devlet arasında gerçek bir bağ tesis edilmeden salt ekonomik katkı temelinde vatandaşlığın verilmesi ve vatandaşlığın metalaşması yatmaktadır.

Çalışmanın bu kısmında hukuki, sosyal ve siyasi açıdan gündeme gelen sorunlar dünyadaki örnekler 1şı̆̆ 1 altında belli başlıklar altında ele alınacak, her bir başlığın içerisinde incelenen sorunun ülkemiz bakımından geçerliliğine dair görüşlerimize de yer verilecektir.

\section{B. Vatandaşlık Bağı}

Devletler tarafından bazı yabancılara sonradan vatandaşlık verilmesinin temelinde bu kişilerin toplum ile sıkı ilişki tesis etmiş olmaları yatmaktadır ${ }^{90}$. Yabancının evlenme ve evlat edinilme gibi ülke ile irtibatını sağlayan başkaca bir bağı yok ise, bu bağ kural olarak ikamet yoluyla sağlanır ${ }^{91}$. Devletler ikamete ilave olarak olağan yoldan vatandaşlı̆ga alınma konusunda dil bilme ve kültürel uyum gibi şartların gerçekleşmesini arayabilmektedir. Bu koşullar da esas itibariyle yabancının ülke ile irtibatını ve bütünleşmesini (entegrasyonunu) amaçlamaktadır ${ }^{92}$. Diğer bir anlatımla, bu şartlar temelde yabancının vatandaşlığına geçmek istediği ülke ile aidiyet bağının tesisini hedeflemektedir ${ }^{93}$. Milli güvenlik ve kamu düzeni bakımından engel teşkil etmemek dışında, ekonomik katkının tek kriter olarak arandığı yatırım yoluyla vatandaşlık uygulamalarında ise, kişinin ülke ile bütünleşmesini sağlayacak gerçek bağın tesisi mümkün olmamaktadır $^{94}$. Türkiye uygulaması da dahil olmak üzere, ikamet şartsız ve ikamet şartlı olmakla birlikte fiili ikametin aranmadığı yatırımcı programlarının aidiyet bağını yeterli ölçüde tesis etmediği kanaatindeyiz.

Vatandaşlığın verilmesi konusunda devletin mahfuz yetkiye sahip olduğu ve yatırım yoluyla vatandaşlık uygulamasının ülkenin ekonomik ihtiyaçlarının karşılanması açısından, bu yetkinin bir kullanış biçimi olduğu şüphesizdir. Bununla birlikte, devlet ekonomik saiklerle söz

${ }^{86}$ SHACHAR, Ayelet: "Beyond Open and Closed Borders: the Grand Transformation of Citizenship", Jurisprudence, 11(1), 2020, s.22; SCHERRER/THIRION, s.20-21.

${ }^{87}$ ANDRIOPOULOU, s.9.

${ }^{88}$ ANDRIOPOULOU, s.8; SCHERRER/THIRION, s.20-21.

${ }^{89}$ GÖLCÜKLÜ, s. 140 .

${ }^{90}$ NOMER, s.75-76.

${ }^{91}$ BAUBÖCK/WALLACE GOODMAN, s.2.

${ }^{92}$ BAUBÖCK/WALLACE GOODMAN, s.4; DZANKIC, Pros and Cons, s.1.

${ }^{93}$ SCHERRER/THIRION, s.24.

${ }^{94}$ SHACHAR, Citizenship for Sale, s.492. 
konusu yetkisini kullanırken vatandaşlık bağına zarar verici uygulamalardan kaçınmalıdır. Bu noktada yatırım yoluyla vatandaşlık uygulamasının istisnai nitelikte bir vatandaşlık verme şekli olduğu ve istisnai nitelikte vatandaşlık uygulamasında işin niteliği gereği, olağan yoldan vatandaşlığa alınma koşullarının bir kısmının aranmayacağı iddia edilebilir. Bununla birlikte, geleneksel istisnai nitelikte vatandaşlık uygulamalarında genel olarak yabancının bilim, teknoloji, ekonomi, sosyal, spor, kültür ve sanat alanlarında haiz olduğu üstün vasıflarını kullanarak ülkeye olağanüstü hizmetinin geçmesi aranmaktadır ${ }^{95}$. Yabancının üstün vasıflarını kullanarak ülke için olağanüstü bir hizmette bulunması toplumla bütünleştiğini göstermektedir ${ }^{96}$. Başka bir anlatımla, istisnai nitelikte vatandaşl1k uygulamasında vatandaşlık verilmesinin sebebi kişinin üstün vasfi ve bu vasfını aktif olarak topluma hizmet için kullanmasıdır ${ }^{97}$. Getirilen ekonomik katkının tek kriter olarak arandığ vatandaşlık uygulamalarında ise kişinin toplumla entegrasyonu ve aidiyet bağı tesisi fikrinden uzaklaşılmakta, getirilen sermaye adeta bir şirkete yapılan yatırım gibi telakki edilmektedir. Yapılan yatırımın karşılığında ise yatırımcı kendisi ve ailesi için vizesiz seyahat, ikamet, daha iyi yaşam, çalışma ve eğitim olanaklarının tümüne veya bir kısmına sahip olmaktadir.

Oysa, vatandaşlık özünde ülkede yaşayan kişilerin karşılıklılık, eşitlik ve dayanışma ilkeleri temelinde yaşadıkları toplumla kurmuş oldukları siyasi ve sosyal bağdır ${ }^{98}$. Vatandaşlık bağ iyi ve kötü zamanlarda topluluğu oluşturan bireylerin bir arada bulunma bilinç ve isteğine işaret eder. $\mathrm{Bu}$ bilinç ve isteğin temelinde ise karşılıklı güven duygusu yatar. $\mathrm{Bu}$ anlamda vatandaşlığın, meblağ ne olursa olsun mali bir bedel karşılı̆̆ında o toplumla aidiyet bağı tesis etmemiş kişilere sağlanması temsil ettiği bu bağı zayıflatacak niteliktedir ${ }^{99}$. Bu noktada ikamet şartlı uygulanan yatırımcı programlarında dahi aidiyet bağının yeterli ölçüde kurulamaması nedeniyle Kanada gibi bazı ülkelerin yatırımcı programlarını sonlandırdıkları not edilmelidir ${ }^{100}$.

\section{Vatandaşlığın Metalaşması}

Salt ekonomik katkı temelinde uygulanan tüm yatırımcı programlarının vatandaşlığı metalaştırdığı kanaatindeyiz. Bu manada yatırım yoluyla elde edilen vatandaşlık yatırımcılar açısından satın alınan bir meta görünümündedir ${ }^{101}$. Yatırımcı, tıpkı bir mal veya hizmet gibi kendisine sunmuş olduğu vizesiz seyahat, sağlık, eğitim, siyasi istikrar gibi olanaklar bağlamında vatandaşlığa bir değer biçmekte ve ilgili ülkenin vatandaşlığına geçip geçmeme konusunda karar vermektedir. Bu durum bir yönüyle vatandaşlığı değerleme konusunda piyasa mekanizmasının devreye girmesi anlamına gelmektedir. Piyasada talep gören vatandaşlığın fiyatı yüksek tutulurken, talep edilmeyen vatandaşlığın değeri düşük seyretmektedir ${ }^{102}$. Ayrıca vatandaşlığa başvurma konusunda sunulan seçeneklerin sayısı ve vatandaşlı̆̆ 1 almak için gerekli süre; vatandaşlığın piyasada ne ölçüde talep edildiğine bağlı olmaktadır. Öte yandan, uluslararası arenada vatandaşlık planlaması ve vatandaşlığa geçiş konusunda danışmanlık hizmeti sunan bir sektör doğmuştur ${ }^{103}$. Danışmanlık şirketleri yatırım yoluyla vatandaşlık veren ülkelerin vatandaşlıklarını, sunmuş oldukları imkanlar ve bedelleri çerçevesinde piyasa mantığı ile bir değerlendirmeye tabi tutarak, müşterilerine en uygun seçeneği sunmaya çalışmaktadır. Bu sektör yalnızca vatandaşlık almak isteyen kişilere değil, aynı zamanda küçük ada devletleri başta olmak üzere pek çok ülkeye yatırımcı programlarının tasarlanması ve pazarlanması konusunda danışmanlık hizmeti vermeye başlamışıı ${ }^{104}$.

Diğer taraftan, vatandaşlığın yatırımcı açısından kullanım değeri ülke içinde sağladığı olanakların yanı sıra uluslararası alanda tanıdı̆̆ 1 kolaylıklara göre anlam ifade etmektedir. Vatandaşlık veren ülkenin yurt dışında vatandaşlarına ne ölçüde diplomatik koruma sağladığı ve özellikle bu ülke pasaportunun diğer ülkelere vizesiz seyahat imkânı tanıyıp tanımadığı vatandaşlığın değerini yakından etkilemektedir. Bu bağlamda örneğin $\mathrm{AB}$ üyesi ülkeler tarafından verilen vatandaşlığın diğer $\mathrm{AB}$ ülkelerine yerleşme ve serbest dolaşım imkânı vermesi, dünyadaki

\footnotetext{
${ }^{95}$ DZANKIC, Pros and Cons, s.2.

${ }^{96}$ BARAN ÇELIK, s.391. DOĞAN, s.74.

97 SHACHAR/HIRSCHL, s.251-252.

${ }^{98}$ ANDRIOPOULOU, s.9-10; SCHERRER/THIRION, s.27.

${ }^{99}$ GÖLCÜKLÜ, s.138; SHACHAR/HIRSCHL, s.249.

100 Government of Canada, Department of Finance, The Road to Balance: Creating Jobs And Opportunities, 2014), s.81, https://www.budget.gc.ca/2014/docs/plan/pdf/budget2014-eng.pdf (Erişim Tarihi: 1.11.2020).

${ }^{101}$ BARAN ÇELİK, s.369.

102 SURAK, Citizenship, s.9.

${ }^{103}$ SUMPTION/HOOPER, s.3.

${ }^{104}$ SCHERRER/THIRION, s.27.
} 
pek çok ülkeye vizesiz seyahat firsatı sunması, bu ülkeler tarafından verilen vatandaşlığın değerini artırmaktadır. Tersine bir durumda, örneğin gelişmiş bir ülkenin yatırım yoluyla vatandaşlık veren ülkeye vize uygulaması, bu ülke tarafından verilen vatandaşlığın değerini düşürmektedir. Nitekim Kanada tarafından St. Kitts ve Nevis'e karşı vize uygulanması bu ülke tarafından verilen vatandaşlığın değerini düşürmüştür ${ }^{105}$.

Yatırım yoluyla vatandaşlık kazanılmasına olanak sağlayan uygulamalarla vatandaşlığın meta halinde getirilmesi, vatandaşlık değerinin arz ve talep gibi piyasa kurallarına göre belirlenmesi, duygu, düşünce ve kader birliği gibi manevi yönleri bulunan vatandaşlık bağına zarar verebilecek niteliktedir ${ }^{106}$. Vatandaşlığın metalaşması aynı zamanda vatandaşlığın itibar değerini de düşürmektedir ${ }^{107}$. Üstelik bu değerin üçüncü ülkelerin kararlarından etkilenmesi, üçüncü ülkelere vizesiz seyahat gibi tüm vatandaşların daha önce sahip oldukları birtakım serbestilerden yararlanmalarını da engelleyebilecek niteliktedir ${ }^{108}$. Diğer bir anlatımla, yatırımcı programları kapsamında vatandaşlığın yaygın bir şekilde verilmesi ve yaşanabilecek ihlaller, yatırım programı uygulayan ülkenin pasaportunun diğer ülkeler nezdindeki güvenirliliğini ve değerini azaltabilecektir.

\section{Güvenlik}

Kişiler bakımından yatırım yoluyla vatandaşlık kazanma isteğinin gerisinde seyahat özgürlügü, güvenli ve siyasî bakımdan istikrarlı olan bir ülkeye yerleşme, nitelikli eğitim ve sağlık hizmetlerine kavuşma ve hatta daha güzel bir iklimde yaşama gibi meşru gerekçeler bulanabileceği gibi, kara para aklama, rüşvet, vergi kaçakçılı̆̆ pek çok suçun işlenmesini kolaylaştırma veya bu suçlar nedeniyle verilmiş cezalardan kurtulma niyeti de bulunabilir. Bu nedenle, yatırım yoluyla vatandaşlık verilmesi öncesinde bu hususların derinlemesine araştırılması, toplumun güvenliği bakımından hayati önemi haizdir. Ülkemiz de dahil olmak üzere yatırım yoluyla vatandaşlık veren tüm devletler, genel olarak vatandaşlığa alınacak kişinin milli güvenlik ve kamu düzeni bakımından tehlike arz etmemesi şartını aramaktadır. İlave olarak Avrupa ülkelerinin pek çoğu yatırım yapılan meblağın yasal yollardan edinildiğinin kanıtlanmasını talep etmektedir ${ }^{109}$.

Ne var ki; vatandaşlığa alınacak kişinin toplumun güvenliği bakımından tehlike oluşturup oluşturmadığı, emniyet teşkilatının yüzeysel incelemeleri ile anlaşılabilecek nitelikte olmayabilir. Bu durum özellikle asayişe ilişkin kayıtların güvenli olarak tutulmadığı, kayıtların alınamadığı, rüşvet ve yolsuzluk gibi yöntemlerle kayıtların kolaylıkla manipüle edildiği ülke vatandaşları bakımından daha belirgindir. Nitekim, Avrupa Parlamentosu'nun 2014 yılı başında Malta tarafından uygulanan yatırımcı programına karşı "satılık vatandaşlık" başlığı ile almış olduğu $\operatorname{karar}^{110}$ sonrasında, pek çok Avrupa ülkesinin yatırımcı programını rüşvet, kara para aklama, ekonomik güvenlik, casusluk, ekonomik yaptırım kararlarını delme gibi olası ihlallere karşı gözden geçirmiş ve güvenlik tedbirlerini sıkılaştırmış olmasına rağmen, müteaddit ihlalin yaşanmış olduğu not edilmelidir ${ }^{111}$. Malta, GKRY, Portekiz, Bulgaristan ve hatta Birleşik Krallık gibi yatırımcı programı uygulayan ülkelerde parlamento kayıtlarına veya basına yansıyan suiistimaller tespit edilmiştir ${ }^{112}$.

Güvenlik ihlallerinin ikamet şartsız veya ikamet şartlı olmakla birlikte fiili ikamet koşulunu aramayan yatırımcı programı uygulayan ülkelerde daha çok yaşandı̆̆ 1 not edilmelidir. Örneğin GKRY tarafından, ülkesinde çeşitli suçlardan hüküm giymiş suçlular ve İnterpol tarafından aranan kişilere vatandaşlık verildiği, hatta işlemlerin kolaylaştırılmasını teminen üst düzey yetkililerin devreye girdiği basına yansımıştır ${ }^{113}$. Bu hususların gerçekliğinin anlaşılması sonrasında ise GKRY 2013 yılından beri uyguladığı ve yaklaşık 8 milyar Euro elde ettiği yatırımcı

\footnotetext{
${ }^{105} \mathrm{XU} / \mathrm{EL}-\mathrm{ASHRAM} / \mathrm{GOLD}, \mathrm{s} .8$.

${ }^{106}$ SHACHAR, Citizenship for Sale, s.805.

107 ŞİT KÖŞGEROĞLU, s.193.

108 SUMPTION/HOOPER, s.17.

${ }^{109}$ SCHERRER/THIRION, s.28.

110 European Parliament resolution of 16 January 2014 on EU citizenship for sale (2013/2995(RSP)), https://www.europarl.europa.eu/doceo/document/TA-7-2014-0038_EN.html (Erişim Tarihi: 16.10.2020)

${ }^{111}$ SCHERRER/THIRION, s.28-29.

112 SCHERRER/THIRION, s.29; https://www.theguardian.com/uk-news/2017/jul/04/golden-visa-immigration-dealbritish-citizenship-home-office (Erişim Tarihi: 3.10.2020).

$113 \mathrm{https}: / /$ www.aljazeera.com/news/2020/10/13/cyprus-abolishes-citizenship-through-investment-programme (Erişim Tarihi: 3.11.2020).
} 
programını 1 Kasım 2020 tarihi itibariyle sonlandırmak zorunda kalmıştır ${ }^{114}$. Ayrıca, ihlaller nedeniyle AB Komisyonu 20 Ekim 2020 tarihinde Malta ve GKRY tarafindan uygulanan yatırımcı programlarına karşı ihlal prosedürü başlatmış, Bulgaristan'a ise yatırım programından duyulan endişeleri içeren bir mektup göndermiştir ${ }^{115}$.

Yatırımcıya önce ikamet izni veren ve ikamet izni süresi boyunca ülkede fiili ikameti arayan ülkelerde dahi güvenlik ihlallerinin yaşandığ 1 konusunda medyada haberler yapılmış olmakla birlikte, bu tür ihlallerin görece daha az yaşandığı görülmektedir. Zira, vatandaşlık öncesinde kişinin ülkede fiili ikametinin aranması (özellikle de yılın yarısından fazlasının ülkede geçirilmesi durumunda) bu tür güvenlik sorunlarının tespitini kolaylaştıracak, akabinde ise ihlalde bulunan kişiye vatandaşl1k verilmeyebilecektir. Başka bir anlatımla, fiili ikamet süresi bir bakıma vatandaşlığa alınma açısından bir kontrol işlevi görecektir ${ }^{116}$. Bu bağlamda ülkemiz yatırım yoluyla vatandaşlık uygulaması açısından ortaya çıkabilecek muhtemel güvenlik sorunlarının engellenmesi bakımından fiili ikamet mecburiyetinin aranmasının gerektiği kanaatindeyiz.

\section{E. Vergi}

Ülkelerin vergilendirme konusundaki farkl1 uygulamaları, öteden beri şirketlerin merkezlerini bir ülkeden diğerine taşımaları konusunda ciddi bir etken olagelmiştir. Gerçek kişiler bakımından ise yalnızca vergiye dayalı vatandaşlık değiştirme sınırlı olarak görülmektedir ${ }^{117}$. Bununla birlikte, diğer sebeplerle zaten vatandaşlığını değiştirecek veya yatırım yoluyla ikinci bir vatandaşlık alacaklar bakımından vergisel avantajlar, yatırımcı programı tercihinde bir etmen olabilmektedir. Özellikle Karayip bölgesinde bulunan ve vergi cenneti olarak anılan ülkelerin yatırımcı programları, vergi konusunu önceleyen yatırımcılarca tercih edilmektedir. Bu kapsamda örneğin Dominika ve St. Kitts ve Nevis kendi ülkelerinde yerleşik olmayan kişi ve şirketlerden neredeyse hiç vergi almamakta ayrıca yatırımcıların çok katı malî gizlilik yasaları ile korunan offshore banka hesapları açmalarına izin vermektedir ${ }^{118}$.

Vergi cenneti ülkeler dışında, Bulgaristan, İtalya ve Portekiz gibi bazı Avrupa ülkeleri de yatırım yoluyla ikamet izni alan veya vatandaşlık kazanan yatırımcılara vergisel birtakım kolaylıklar tanımaktadır. Bu kapsamda örneğin Bulgaristan yeni vergi mükelleflerine \%10 gibi sabit bir oran uygulamakta, Portekiz ise yatırımcılara 10 yıl süre ile vergi indirimi ve yurtdışından kazanılan gelir ve kazançları vergi matrahından istisna tutma gibi kolaylıklar sunmaktadır ${ }^{119}$. İtalya ise benzer bir kolaylığı yatırımcıların 100.000 Euro ikame vergi (substitute tax) ödemeleri kaydiyla yapmaktadır ${ }^{120}$.

Vergisel teşvikler yoluyla yatırımcılara imtiyazlı muamelede bulunulması vergi adaletinin bozulmasına yol açabilecek niteliktedir. Nitekim İtalya' da yatırımcılar yurt dışından elde ettikleri gelir ve kazançlar için maktu bir vergi ödeyerek vergisel yükümlülüklerinden kurtulabilmekte iken, yerleşikler \%43'e varan vergi ödeyebilmektedir ${ }^{121}$. Oysa demokratik toplumlarda vergi oran ve miktarları vatandaşlık veya mukimlik statüsünün kazanılması zamanına göre değil, hakkaniyet ve ödeme gücüne göre belirlenir ${ }^{122}$. Kriz zamanlarında vergisel teşviklerin de etkisiyle ülkeye çekilen yatırımcılarca getirilen ekonomik katkının krizin etkisini azaltacağı, bu bağlamda vergisel teşviklerin kamunun menfaatine olduğu iddiası öne sürülebilir. Bununla birlikte bu menfaat ülkede vergi adaletinin korunması gibi başka bir kamusal menfaatin zedelenmesine yol açmamalıdır ${ }^{123}$.

\footnotetext{
${ }^{114}$ KAMBAS, Michele: After Outcry, Cyprus Suspends its Citizenship for Cash Programme, https://www.reuters.com/article/cyprus-citizenship-int-idUSKBN26Y17D (Erişim Tarihi: 8.11.2020).

${ }_{115}$ European Commission: Press release, Investor citizenship schemes: European Commission opens infringements against Cyprus and Malta for "selling" EU citizenship, 20 October 2020, https://ec.europa.eu/commission/presscorner/detail/en/ip_20_1925 (Erişim Tarihi: 13.11.2020)

${ }^{116}$ Krakat Michael B.: "Genuine Links Beyond State and Market Control: The Sale of Citizenship by Investment in International and Supranational Legal Perspective", Bond Law Review, 30(1), 2018, s.148.

117 Son yıllarda ülkeleri dışında yaşayan bazı ABD vatandaşlarının; ABD vergi sisteminin karmaşıklığı ve her yıl vergi beyannamesi doldurmanın maliyeti nedeniyle vatandaşlıklarını bıraktıkları ifade edilmektedir. Bkz. SOLIMANO, s.7. 118 ADIM, Investment, s.123.

${ }^{119}$ ADIM, Investment, s.123.

${ }^{120}$ CHRISTIANS, Allison: "Buying in: Residence and Citizenship by Investment”, 62 St. Louis U. L.J. 51, 2017, S.51.

${ }^{121}$ CHRISTIANS, s.51.

${ }^{122}$ ADIM, Investment, s.126.

${ }^{123}$ ADIM, Investment, s.126.
} 
Türkiye gibi yatırımcı programı uygulayan pek çok ülke ise yatırım yoluyla vatandaşlık kazanan kişiler ile diğer vatandaşlar arasında vergilendirme bakımından herhangi bir ayrıma gitmemektedir. Nitekim Gelir Vergisi Kanunu'nun ${ }^{124} 5$ 'inci maddesi "bir takvim yll içinde Türkiye'de devamlı olarak altı aydan fazla oturanlar"1n gelir vergisi ödeyeceğini belirtmekte, 6'incı maddesi ise Türkiye'de yerleşik olmayanların sadece Türkiye'de elde ettikleri kazanç ve iratlar üzerinden vergilendirileceğini açılamaktadır. Bu anlamda vergisel teşvik içermemesi nedeniyle, ülkemiz uygulamasının bu başlık altında ele alınan sorunu doğurmayacağı kanaatindeyiz.

\section{F. Seçme ve Seçilme hakkı}

Vatandaşlığın kazanılmasının en önemli sonuçlarından biri de şüphesiz yatırımcının siyasî hak ve ödevler arasında sayılan seçme ve seçilme hakkına sahip olmasıdır. Seçme ve seçilme hakkı, gerek vatandaşlığı “en yüksek siyasi onur" olarak ele alan Aristo'nun vatandaşlık anlayışı gerek vatandaşlığı hukukî statü olarak ele alan modern anlayış kapsamında kural olarak aslen ve sonradan kazanan vatandaşlar arasında herhangi bir ayrım yapılmadan tüm vatandaşlara eşit olarak tanınmaktadır ${ }^{125}$. Bununla birlikte, sosyolojik açıdan ülke ile gerçek bir bağ tesis etmemiş kişilere yatırım yoluyla vatandaşlık verilmesi ülkenin siyasi yapısı ve sistemine yatırım yoluyla müdahalenin önünü açmaktadır ${ }^{126}$. Bu etki özellikle az bir nüfusa sahip ada devletleri bakımından daha rahat görülebilmektedir. Esasen bu etkinin farkında olan pek çok ada devleti seçimlerde ülke dışından oy kullanmaya sınırlamalar getirmiştir. Nitekim Antigua ve Barbuda, GKRY, Dominika, Grenada, Malta ve Saint Lucia vatandaşlarının seçimlerde oy kullanmaları için seçimden önce ülkede 3 ay, 6 ay ve 1 y1l gibi sürelerle ikametini şart koşmuşlardır ${ }^{127}$.

Türkiye gibi kalabalık nüfusa sahip ülkeler bakımından yatırım yoluyla vatandaşlık kazanan kişilerin oyları seçim sonuçları üzerinde ciddi bir etkiye sahip olmayacaktır. Ancak bazı durumlarda yatırım yoluyla vatandaşlık kazanan kişilerin tutumları seçim sonucu etkileyebilecektir. Örneğin oyların çok yakın seyrettiği mahalli seçimlerde tek bir oy bile önemli olabilmektedir. Bu noktada yatırım yoluyla vatandaşlık uygulamasından kaç kişinin yararlandığ bu hususta yorum yapmak bakımından önem arz etmektedir.

\section{G. Askerlik}

Geçmişte askerlik ve vatan savunmasına katılma, vatana bağlılığın en somut göstergelerinden birisi olarak kabul edilmiştir. Hatta askerlik hizmetinden kaçınma vatandaşlıktan çıkarılma sebebi olarak sayılmıştır ${ }^{128}$. Günümüzde ise ülkelerin askeri güçlerini silah altında bulanan askerlerin sayısından ziyade teknolojik üstünlükleri belirlemektedir. Pek çok ülke ordularında görev alan askeri personelin sayısını azaltmakta ve profesyonel askerlik sistemine geçmektedir. $\mathrm{Bu}$ anlamda askerlik hizmeti zorunlu olarak yapılacak bir görev olmaktan çıkmaktadır. Türkiye de 2019 yılında kabul ettiği Askeralma Kanunu ${ }^{129}$ ile profesyonel askerliğe geçiş konusunda önemli bir atmış, bir yandan askerlik süresini kısaltmış diğer yandan ise zorunlu askerlik hizmetinin bedelli olarak yapmasına imkân tanımıştır. Diğer yandan dünyanın pek çok ülkesi bir adım daha ileri giderek ordularında profesyonel yabancı askerler istihdam etmektedir ${ }^{130}$. $\mathrm{Bu}$ durum yatırım yoluyla vatandaşlık uygulamalarını kolaylaştırmıştır. Zira askerlik hizmetinin zorunlu olmadığı ülkeler bakımından bu husus bir yandan programın pazarlanmasını kolaylaştırmakta, diğer yandan vatandaşlık hak ve yükümlülükleri açısından vatandaşlar arasında ayrımcılık yapıldığı yönündeki eleştirileri ortadan kaldırmaktadır. Bununla birlikte, ülke güvenliği her ne kadar profesyonel askerler tarafından yerine getirilse de savaş veya olağanüstü durumlarda tüm vatandaşların hizmetine ihtiyaç duyulabilmektedir. Bu nedenle yatırım yoluyla vatandaşlık uygulamalarında askerlik ve vatan savunmasına katılma hususları göz önüne alınması gereken hususlardandır.

\section{H. Ekonomik Fayda}

Yatırım yoluyla vatandaşlık uygulamalarının devletler bakımından temel motivasyonu ekonomik kaynak yaratmak düşüncesidir. Yakın zamanda yapılan araştırmalar ise yatırım yoluyla

\footnotetext{
${ }^{124}$ RG: 06.01.1961; 10700

125 ANDRIOPOULOU, s.2.

126 BAUBÖCK, s.39.

127 SURAK, Citizenship, s.6.

128 GÖGER, s. 150 .

${ }^{129}$ RG: 26/6/2019; 30813.

${ }^{130}$ SURAK, Citizenship, s.11.
} 
vatandaşlık uygulamalarından gelen katkının beklenilenin çok altında olduğunu göstermiştir ${ }^{131}$. Nitekim, yatırımcılar açısından yatırım yoluyla vatandaşlığa başvurmanın temel motivasyonu ülke ile aidiyet bağının tesisinden ziyade vatandaşlığın sağladığı imkânlardan yararlanmaktır ${ }^{132}$. $\mathrm{Bu}$ nedenle, yatırımcılar vatandaşlığın kazanılması için gereken minimum sürenin ardından yatırımlarını nakde çevirerek ülke dışına çıkarabilmektedir ${ }^{133}$. Bu anlamda yatırım yoluyla vatandaşlığın maddi değeri aslında getirilen kaynağın öngörülen sürenin başındaki ve sonundaki değeri arasındaki fark şeklinde tezahür etmektedir. Örneğin kişinin üç yıl süre ile elde tutmak şartıyla gayrimenkulü satın alımı yoluyla yatırım yaptığını düşünelim. Gayrimenkul, vatandaşlığa başvuru esnasında 250.000 Dolar, üçüncü yılın sonunda 220.000 Dolar ediyor ise vatandaşlığın yatırımcıya maliyeti esas itibariyle 30.000 Dolar +250.000 Doların alternatif bir yatırım aracında değerlendirmiş olsa idi getireceği gelirden başka bir şey değildir. Gayri menkulün süreç sonunda 250.000 Dolar ve üstünde bir bedel ile satılabilmesi halinde ise yatırımcının maliyeti minimal düzeyde olabilecek hatta yatırımdan karlı bile çıkabilecektir. Verilen bu örneğin ülkemiz uygulaması bakımından da geçerli olduğu kanaatindeyiz. Bu anlamda yatırım bir üretim aracına yönlendirilmediği müddetçe yatırım yoluyla vatandaşıı̆ıı ülkeye katkısı geçici ve minimal düzeyde kalmakta, gerçek anlamda ülkenin kalkınmasına hizmet etmemektedir.

Gerçekten de İrlanda tarafından halihazırda yürürlükte olmayan yatırımcı programı kapsamında yatırımcının beş yıl süre ve sıfır faiz ile 1 milyon Euro tutarında devlet tahvili alması programdan yararlanmak için yeterli sayılmış idi. Yapılan hesaplamalar ise 2010- 2015 yılları arasında vatandaşlığın gerçek maliyetinin sadece 22.000 Euro olduğunu göstermiştiir ${ }^{134}$. Keza Kanada 1986 yılından itibaren uyguladığı yatırımcı programını, beklenilen ekonomik katkıyı sağlamaması nedeniyle 2012 yılında askıya almış 2014 yılında ise sonlandırmışıırı ${ }^{135}$. Zira Kanada vatandaşlı̆̆ için başvuran yatırımcıların önemli bir kısmı, asgari gerekleri karşılayıp Kanada vatandaşlı̆̆ını kazandıktan sonra, ülkede ikamet etmemiş, yatırımlarını da nakde çevirerek ülke dışına aktarmışlardır.

\section{V.SONUÇ}

Ülkelerin ekonomik ve toplumsal gelişimi açısından sermaye ve ekonomik sermayeyi değere dönüştürecek insan kaynağı hayatî önemi haizdir. Bu bağlamda gelişmiş veya gelişmekte olan ülke statüsü fark etmeksizin, ekonomik sermaye ve vasıflı insan arayışında olan pek çok ülke sermaye sahibi nitelikli yabancıları ikamet izni veya vatandaşlık hakkı tanınması yoluyla ülkelerine çekmek istemektedir. Ekonomik sermaye ve daha da önemlisi vasıflı insan kaynağını ülkeye kazandırmak bakımından bu şekilde bir yönelimin yerinde ve makul olduğu açıktır. Ancak yabancı kişinin vatandaşı̆ğa alınması ile sonuçlanabilecek uygulamaların kişinin toplumla gerçek vatandaşlık bağını tesis eder şekilde tasarlanması gerekmektedir.

Kanaatimizce kişinin ülkeye getireceği sermayenin büyüklüğünden ziyade, girişimcilik, sanayi tesis kurma ve istihdam yaratma gibi niteliklerinin arandığı yatırım yoluyla vatandaşlık uygulamalarında, kişinin toplumla olan gerçek vatandaşlık bağı daha kolay bir şekilde kurulacaktır. Zira kişi ülkeye getirdiği sermayeyi kişilik vasfı ile birleştirerek vatandaşlığa geçmek istediği ülkenin hizmetine sunmakta, diğer bir anlatımla, aktif bir tutum sergileyerek toplumla bütünleştiğini göstermektedir. Buna mukabil, son 30 yılda uygulandığ 1 şekli ile sermayeyi önceleyen, kişinin niteliğini arka plana atan geniş kapsamlı yatırımcı programlarının kişi ile toplum arasında benzer bir bütünleşmeği sağlayamadığı görülmektedir. Zira yatırımcı programları, genel olarak uygulayan ülkenin ihtiyaçları ve yatırımcılar tarafindan ne ölçüde tercih edildiklerine bağlı olarak piyasa mantığına göre şekillenmektedir. Dünyadaki örnekler ise piyasa mantığı ile şekillenen yatırımcı programlarının aidiyet hissini de içeren, bu bağlamda manevi boyutu da bulunan, vatandaşlık bağının kurulması açısından doğru sonuçlar üretmediğini göstermiştir. Özellikle ikamet şartsız veya ikamet şartlı olmakla birlikte filli ikametin aranmadığ 1 yatırıme programları bu bağı kurmakta yetersiz kalmıştır. Oysa vatandaşlık, kişinin yalnızca ortak yaşamın getirdiği imkânlardan yararlanmasını sağlayan bir araç değil, aynı zamanda ortak yaşamın yükünü paylaşmayı da içeren bir bağl1l1k taahhüdüdür. Bu bağl1lık taahhüdü göz ardı edilerek verilen vatandaşlığın, özellikle güvenlik, vergi, seçme ve seçilme hakkı ile askerlik gibi

\footnotetext{
${ }^{131}$ SHACHAR, Citizenship for Sale, s.801; SURAK, Citizenship, s.18.

132 SHACHAR, Citizenship for Sale, s.802.

${ }^{133}$ SURAK, Citizenship, s. 18.

${ }^{134}$ SURAK, Citizenship, s.18.

${ }^{135}$ SUMPTION/HOOPER, s.19.
} 
alanlarda sorunlar çıkarması muhtemeldir.

Diğer yandan, dünyadaki örnekler, yatırımcı programlarından elde edilen gelirlerin uzun vadede ülke ekonomisine katkısının minimal düzeyde kaldığına işaret etmektedir. Ayrıca mikro devletlerdeki uygulamalar bir kenara bırakılırsa, yatırım yoluyla vatandaşlık verilmesi konusundaki uluslararası gelişmeler ikamet şartsız ve ikamet şartlı olmakla birlikte filli ikametin aranmadığı uygulamaların yavaş yavaş terk edildiğini göstermektedir. Ayrıca, ABD ve Birleşik Krallık gibi ülkelerde görece başarılı olarak uygulanan ikamet şartlı yatırımcı programları, aidiyet bağının asgari düzeyde de olsa tesis edilmesinin önemini ortaya koymuştur.

Bu veriler 1şığında yatırım yoluyla vatandaşlık mevzusunda Türkiye'nin kişinin niteliğini ön plana alan istisnai nitelikli yatırım yoluyla vatandaşlık uygulamalarına öncelik vermesi gerektiğini değerlendirmekteyiz. Öte yandan, hâlihazırda tatbik edilen yatırımcı programından vazgeçilmesi veya en azından programının vatandaşlık verilecek kişinin ülke ile aidiyet bağını tesis edecek şekilde gözden geçirilmesi yerinde olacaktır. Vatandaşlık bağının asgari düzeyde de olsa tesisi bakımından yatırım eşiğinin yükseltilmesi, yatırımcıya öncelikle ikamet izni verilmesi ve bu dönemde ise fiili ikametin aranması isabetli olacaktır.

KAYNAKÇA

ADIM, Leila: Residence and Citizenship by Investment: An Updated Database on Immigrant Investor Programs, (Database) http://dx.doi.org/10.2139/ssrn.3474396, (Erişim tarihi: 11.11.2020).

ADIM, Leila: Between Benefit and Abuse: Immigrant Investment Programs, 62 St. Louis U. L.J., 2017, s.121-136 (Investment).

ANDRIOPOULOU Athanasia: The "ius pecuniae": The Prize of Citizenship, BRIDGE Network - Working Paper 4, 2020.

AYBAY, Rona/ÖZBEK, Nimet/ERSEN PERÇi̇N, Gizem: Vatandaşlık Hukuku, 2019.

BAUBÖCK Rainer/WALLACE GOODMAN Sara: Naturalisation, EUDO Citizenship, Policy Brief No.2, s.7

https://cadmus.eui.eu/bitstream/handle/1814/51625/RSCAS_EUDO_CIT_PB_201

1_02.pdf?sequence=1 (Erişim Tarihi: 15.10.2020).

BAUBÖCK, Rainer: What Is Wrong with Selling Citizenship? It Corrupts Democracy!, Debating Transformations of National Citizenship. IMISCOE Research Series Bauböck R. (ed), Springer, 2018.

BARAN ÇELİK, Neşe: “Güncel Gelişmeler Işı̆̆ında Türk Vatandaşlığının İstisnai Haller Kapsamında Kazanılması", Türkiye Barolar Birliği Dergisi 130, 2017, s.357-418.

CHRISTIANS, Allison: "Buying in: Residence and Citizenship by Investment", 62 St. Louis U. L.J. 51, 2017, s.51-72.

DZANKIC, Jelena: The pros and cons of ius pecuniae: Investor Citizenship in Comparative Perspective. Florence: European University Institute Working Papers, RSCAS 2012/14, 2012 (Pros and Cons).

DZANKIC, Jelena: Citizenship with a Price Tag: The Law and Ethics of Investor Citizenship Programmes, Northern Ireland Legal Quarterly 65(4), 2014, s.387-404 (Price Tag).

DZANKIC, Jelena: Investment-based Citizenship and Residence Programmes in the EU, EUI RSCAS, 2015/08, [GLOBALCIT], EUDO Citizenship Observatory, (Citizenship).

DOĞAN, Vahit., Türk Vatandaşlık Hukuku, 16. Bası (Tıpkı Basım), 2020.

ERDEM, B. Bahadır: Türk Vatandaşlık Hukuku, 7. Baskı, 2019.

GÖLCÜKLÜ, İlyas: “Güncel Gelişmeler Işı̆̆ında Yatırım Yoluyla Türk Vatandaşlığının Kazanılması: Problemler ve Çözüm Önerileri”, Public and Private International Law Bulletin 40(1), 2020, s.125-141.

GÜNGÖR, Gülin: Tabiiyet Hukuku, 8. Bası, 2020.

KAMBAS, Michele: After Outcry, Cyprus Suspends its Citizenship for Cash Programme, https://www.reuters.com/article/cyprus-citizenship-int-idUSKBN26Y17D (Erişim Tarihi: 8.11.2020).

KRAKAT, Michael B: "Genuine Links Beyond State and Market Control: The Sale of Citizenship by Investment in International and Supranational Legal Perspective”, Bond Law Review, Vol. 30(1), 2018, s.145-184

NOMER, Engin: Türk Vatandaşlık Hukuku, 27. Bası, 2020.

ÖZKAN Işı1: "Vatandaşlık Satılabilir Birşey midir?”, Uluslararası Sanat Kültür ve İletişim Dergisi, 1(1), 2018, s.53-78.

SHACHAR, Ayelet: "Beyond Open and Closed Borders: the Grand Transformation of Citizenship", Jurisprudence, 11(1), 2020, s.1-27.

SHACHAR, Ayelet: Citizenship for Sale?, Oxford Handbook of Citizenship, Shachar A./Bauböck 
R.,/Bloemraad I., Vink M. (edt.), Oxford University Press, 2017, (Citizenship for Sale).

SHACHAR, Ayelet/HIRSCHL Ran: "On Citizenship, States, and Markets", The Journal of Political Philosophy: 22(2) 2014, s.231-257.

SCHERRER, Amandine/THIRION, Elodie: Citizenship by Investment (CBI) and Residency by Investment (RBI) Schemes in the EU State of Play, Issues and Impacts, European Parliamentary Research Service, 2018.

SOLIMANO, Andrés, Investment Migration, Economic Development and the UN Sustainable Development Goals, Investment Migration Council, and International Centre for Globalisation and Development, 2020.

STILLER, Martin: Pathways to Citizenship for Foreigners in Austria, International Organization for Migration, 2020.

SUMPTION, Madeleine/HOOPER, Kate: Selling Visas and Citizenship: Policy Questions from the Global Boom in Investor Immigration. Washington, DC: Migration Policy Institute, 2014.

SURAK, Kristin: Global Citizenship 2.0 The Growth of Citizenship by Investment Programs, Investment Migration Working Papers IMC-RP2016/3, 2016, (Citizenship).

SURAK, Kristin: Millionaire Mobility and the Sale of Citizenship, Journal of Ethnic and Migration Studies, 2020, Ahead of Print, s.1-24 (Mobility),

ŞiT KÖŞGEROĞLU, Banu: "İstisnai Yoldan Vatandaşlığın Kazanılmasına İlişkin Genel Esaslar ve Son Değişiklikler Çerçevesinde Türk Vatandaşlığının İstisnai Yoldan Kazanılması”, Hacettepe Hukuk Fakültesi Dergisi, 7(1), 2017, s.169-198.

TURAN, Turgut/TANRIBILİR, Feriha Bilge:Vatandaşlık Hukuku, 4. Bası, 2017.

XU, Xin/EL-ASHRAM, Ahmed/GOLD, Judith: Too Much of a Good Thing? Prudent Management of Inflows under Economic Citizenship Programs, IMF Working Paper, Western Hemisphere Department, 2015.

Rapor ve internet siteleri

European Commission: Press release, Investor citizenship schemes: European Commission opens infringements against Cyprus and Malta for "selling” EU citizenship, 20 October 2020, https://ec.europa.eu/commission/presscorner/detail/en/ip_20_1925 (Erişim Tarihi: 13.11.2020. İnternet kaynaklarının erişim tarihi kaynakçada be lirtilmez, atıfta belirtilir.

European Commission: Commission Staff Working Document, Accompanying the Document Report From the Commission to the European Parliament, the Council, the European Economic and Social Committee and the Committee of the Regions, Investor Citizenship and Residence Schemes in the European Union, $\{\mathrm{COM}(2019) 12$ final $\}$, (Document).

European Parliament Resolution of 16 January 2014 on EU citizenship for sale (2013/2995(RSP)), https://www.europarl.europa.eu/doceo/document/TA-7-2014-0038_EN.html (Erişim Tarihi: 16.10.2020).

Government of Canada, Department of Finance, The Road to Balance: Creating Jobs And Opportunities, 2014), s.81, https://www.budget.gc.ca/2014/docs/plan/pdf/budget2014-eng.pdf (Erişim Tarihi: 1.11.2020).

Henley\&Partners: Austria Citizenship-by-Investment Factsheet, https://www.henleyglobal.com/citizenship-austria/(Erişim Tarihi: 25.10.2020).

Henley\&Partners: Investment Migration Programs 2020, The Definitive Comparison of the Leading Global Residence and Citizenship Programs, 5th ed., 2020.

United States Citizenship and Investment Services: https://www.uscis.gov/working-in-the-unitedstates/permanent-workers/employment-based-immigration-fifth-preference-eb5/about-the-eb-5-visa-classification (Erişim Tarihi: 25.10.2020).

United States Citizenship and Investment Services: https://www.uscis.gov/working-in-the-unitedstates/permanent-workers/employment-based-immigration-fifth-preference-eb-5/eb5-investors, (Erişim Tarihi: 25.10.2020).

United States Citizenship and Investment Services, https://www.uscis.gov/policy-manual/volume-12-partd-chapter-3 (Erişim Tarihi: 26.10.2020).

https://www.aljazeera.com/

https://www.enterprisegreece.gov.gr/

https://www.theguardian.com/uk

https://travel.state.gov/ 